Provided for non-commercial research and education use. Not for reproduction, distribution or commercial use.

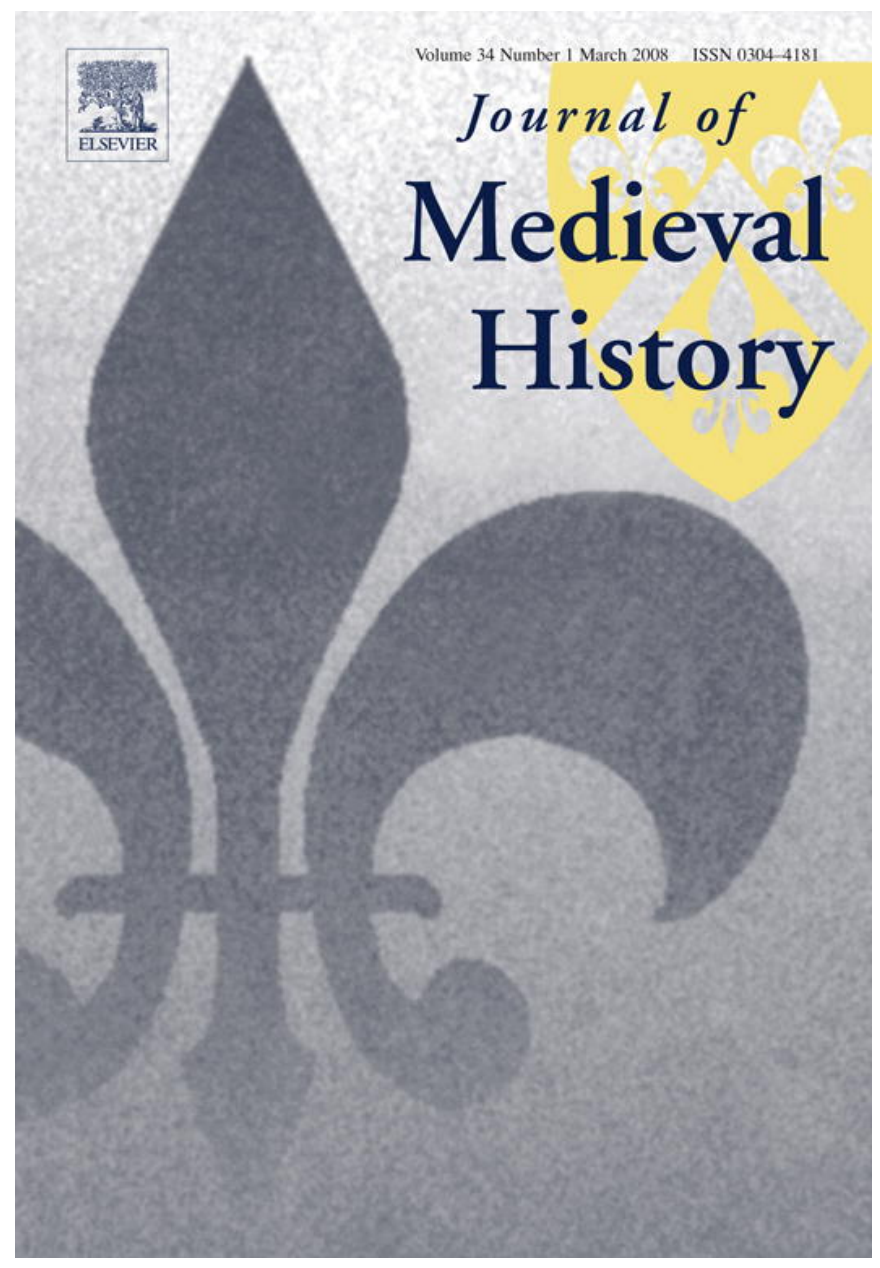

This article was published in an Elsevier journal. The attached copy

is furnished to the author for non-commercial research and education use, including for instruction at the author's institution, sharing with colleagues and providing to institution administration.

Other uses, including reproduction and distribution, or selling or licensing copies, or posting to personal, institutional or third party websites are prohibited.

In most cases authors are permitted to post their version of the article (e.g. in Word or Tex form) to their personal website or institutional repository. Authors requiring further information regarding Elsevier's archiving and manuscript policies are encouraged to visit: 


\title{
'Grace for the rebels': the role of the royal pardon in the Peasants' Revolt of 1381
}

\author{
Helen Lacey
}

Mansfield College, University of Oxford, Oxford OX1 3TF, United Kingdom

\begin{abstract}
This article focuses on the Peasants' Revolt of 1381 as a means of examining some of the late medieval assumptions about the nature of royal mercy. Rather than adding to the weight of scholarship on the causes and characteristics of the Revolt, this article discusses the views on mercy ('grace for the rebels') ${ }^{1}$ that were reportedly expressed by all parties during the course of the rebellion. The first section analyses the chronicles and their references to discussion of pardon and mercy during the revolt itself. The second section examines the role of the royal pardon in the subsequent judicial proceedings in the Home Counties - who were the first recipients of pardon, and how were they able to secure royal grace? The final section then discusses the formulation of the pardon in the autumn parliament, and the debate surrounding the course of government policy in the wake of revolt on an unprecedented scale. This article seeks to demonstrate that the Crown and commons shared a common language of pardon, and understood that by framing their discussion in terms of royal grace, they were alluding to a particular kind of idealised relationship between the king and his subjects.
\end{abstract}

(C) 2007 Elsevier Ltd. All rights reserved.

Keywords: Peasants’ Revolt of 1381; Pardon; Mercy; Richard II

On 13 December 1381 a schedule of pardon for all those involved in the recent insurrection was put before parliament. Richard II authorised this grant of royal mercy, and in so doing he offered grace to all his subjects, both those accused of rebellion and those who had remained loyal.

E-mail address: helen.lacey@mansfield.ox.ac.uk

${ }^{1}$ The parliament rolls of medieval England [hereafter PROME], ed. C. Given-Wilson et al. (CD-ROM. Scholarly Digital Editions, Leicester, 2005), 'Richard II: parliament of 1381, text and translation', item 30. I would like to thank the audience of the Oxford Medieval History Seminar for their advice on an early version of this paper, and Mark Ormrod for his helpful comments on this essay in draft form. 
Considering the volume of scholarship generated on the Peasants' Revolt, the subject of pardon has only ever been given fleeting reference. This is somewhat surprising in light of the longrunning debate on how best to characterise government reaction to the rebels and their demands - did the Crown exercise commendable moderation in dealing with the rebels, as Barrie Dobson claimed, or was there in fact a vindictive campaign of repression? ${ }^{2} \mathrm{~J}$. A. Tuck's work on the parliament held in the autumn of 1381 emphasised the differing stance of the Lords and Commons, the latter championing the policy of moderation which was eventually adopted. ${ }^{3}$ More recently, Andrew Prescott has suggested that we have glossed over the events in London in the immediate aftermath of the revolt, because of the absence of the relevant legal records. He argues that through the chroniclers we get a true picture of the extent of the devastation in London, with rebels being put to the sword or hanged in their thousands. ${ }^{4}$ Rather than enter into the debate about the number of rebels sentenced to death, this article is an attempt to examine some of the ideas about the nature of royal mercy that were thrown into relief by the events of 1381 . The chroniclers suggested that all parties involved at the height of the revolt in London made some reference to the notion of royal grace. The royal pardon also played a significant role in the subsequent judicial proceedings and in the parliamentary debates. The records generated by the revolt thus allow us to examine some of the late medieval assumptions about the nature of royal mercy, assumptions it was perhaps only necessary to articulate at a time of such unprecedented crisis.

Historians have tended to use the chronicle accounts of the Peasants' Revolt to try to reconstruct a picture of 'what actually happened' in the summer of 1381. However, in several recent studies the focus has shifted towards the role of the chroniclers in crafting their own narratives, and the textual conventions behind their accounts. ${ }^{5}$ This emphasis on the construction of the texts is pertinent to the present study, which seeks to explore the way in which perceptions of royal mercy were expressed by contemporaries. The fact that several chroniclers mentioned concepts of mercy and pardon in the context of the revolt is interesting as much for what it says about the

\footnotetext{
2 The Peasants' Revolt of 1381, ed. R.B. Dobson, 2nd edn (London, 1983), 303-4. This question has also been addressed by W.M. Ormrod, 'The Peasants' Revolt and the government of England', Journal of British Studies, 29 (1990), 22; R.W. Kaeuper, War, justice and public order. England and France in the later middle ages (Oxford, 1988), 362; J. A. Tuck, 'Nobles, commons and the great revolt of 1381', in: The English rising of 1381, ed. R.H. Hilton and T.H. Aston (Cambridge, 1984), 194-212. Attention has also been given to the government response in the more general works of N. Saul, Richard II (London, 1997), 56-82; A. Musson and W.M. Ormrod, The evolution of English justice. Law, politics and society in the fourteenth century (Basingstoke, 1999), 96-101. For the traditional view see: T.F. Tout, Chapters in the administrative history of medieval England, 6 vols (Manchester, 1920-33), vol. 3, 356-84; A. Steel, Richard II (Cambridge, 1941); A. Tuck, Richard II and the English nobility (London, 1973), 1-57. Andrew Prescott's unpublished doctoral thesis includes a valuable analysis of the pardons granted in the aftermath of the revolt: A.J. Prescott, 'The Judicial records of the Rising of 1381' (unpublished Ph.D. thesis, London, 1984), 350-62.

3 Tuck, 'Nobles, commons', 205-12; Ormrod, 'Government', 23.

4 A. Prescott, "'The hand of God": the suppression of the Peasants' Revolt of 1381', in: Prophecy, apocalypse and the day of doom: proceedings of the 2000 Harlaxton Symposium, ed. N. Morgan (Donnington, 2004), 317-41.

5 D. Pearsall, 'Interpretative models for the Peasants' Revolt', in: Hermeneutics and medieval culture, ed. P.J. Gallacher and H. Damico (New York, 1989), 63-70; W.M. Ormrod, 'In bed with Joan of Kent: the king's mother and the Peasants' Revolt', in: Medieval women: texts and contexts in late medieval Britain. Essays for Felicity Riddy, ed. J. Wogan-Browne et al. (Turnhout, 2000), 277-92. For a later context, see: D. Grummitt, 'Deconstructing Cade's rebellion: discourse and politics in the mid fifteenth century', in: The fifteenth century VI, identity and insurgency in the late middle ages, ed. L. Clark (Woodbridge, 2006), 107-22.
} 
approach of these writers and the way they constructed their narratives of the rising, as for anything it might reveal about the attitude of those who participated in the revolt. According to Froissart, for example, the council had been discussing the idea of reconciliation even as the rebels gathered outside London. ${ }^{6}$ The insurgents had also declared their desire to be reconciled with the king from the outset, in line with their consistent protestations of loyalty to Richard, which have been noted elsewhere. ${ }^{7}$ At one level we can examine Froissart's comments in light of the literary conventions to which he conforms. At another level we can explore the context of these ideas in other texts, not only in other chronicles but also in the documents produced by the rebels, by the government and by the royal courts, to understand better how these concepts evolved and circulated among different social groups. It may be that we should view overtures to reconciliation on the part of the Crown and the rebels in a cynical light; as rhetoric which both sides were obliged to utilise in order to avert crisis, and to avoid charges of treason. However, it is worth exploring the context of such ideas in more detail, before dismissing them too readily out of hand.

Looking first at the motives the insurgents expressed for their march on London, it is clear that we should not strive to separate the 'authentic voice' of Wat Tyler and his followers from that of the chronicler - even the vernacular letters that circulated among the rebels survive because of their insertion into the narratives of Walsingham and Henry Knighton. ${ }^{8}$ Similarly the actions taken by the rebels are reported to us via the chronicles. Rather than assuming that one narrative stands in the way of our understanding of the other, however, it is perhaps more helpful to recognise the degree to which the two are mutually dependant, and perhaps draw on concepts of mercy or of corruption, for example, that were common to both. One idea promoted in these narratives is the sense that the rebels had been forced to bring their grievances to the attention of the king and council because of the corruption and inertia of the Crown's officers in the localities. This was a familiar concept - complaint about the corruption of local officials had long featured in so-called 'protest literature', in outlaw ballads and in petitions to parliament. ${ }^{9}$ The Anonimalle chronicle brought to mind such ideas by claiming

\footnotetext{
${ }^{6}$ Peasants' Revolt, ed. Dobson, 189-90.

${ }^{7}$ The Anonimalle chronicle notes that the rebels in Kent met at Dartford on 5 June, and 'said among themselves ... that they would neither suffer nor have any king except King Richard.' A few days later they had arrived in Canterbury, and forced the mayor, bailiffs and commons to swear to be 'faithful and loyal to King Richard and the loyal commons of England'. By the time they arrived at Blackheath on 11 June they were declaring to the king's messengers that they had risen 'to save him [the king] and to destroy traitors to him and the kingdom.' Walsingham notes that the Kentish rebels blocked the pilgrimage routes into Canterbury, stopping all the pilgrims and forcing them to swear that they would be faithful to King Richard. Again, Froissart reports that the rebels at Blackheath sent a messenger to the king to 'shew him how all that they have done or will do is for him and his honour'. Peasants' Revolt, ed. Dobson, 127, $129,133,141$. Alastair Dunn uses the term 'populist royalism' to describe these declarations of loyalty. A. Dunn, The great rising of 1381, the Peasants' Revolt and England's failed revolution (Stroud, 2002), 58.

8 Peasants' Revolt, ed. Dobson, 381-3.

${ }^{9}$ Poems such as The simonie and Winner and waster attacked the venality of the courts, as did outlaw romances such as the Tale of Gamelyn and the Robin Hood ballads. More specific injustices were depicted in the Outlaw's song of Trailbaston, while Piers Plowman provided a far-reaching denunciation of judicial corruption. For discussion of such texts see: J.R. Maddicott, 'Poems of social protest in early fourteenth century England', in: England in the fourteenth century: proceedings of the 1985 Harlaxton Symposium, ed. W.M. Ormrod (Woodbridge, 1986), 130-44; Thomas Wright's political songs, ed. P.R. Coss (Cambridge, 1996), 224-30, 323-45; Political poems and songs, ed. T. Wright (Rolls Series 14, London, 1859-61); J. Coleman, English literature in history 1350-1400. Medieval readers and writers (London, 1981), 58-156; R.F. Green, A crisis of truth, literature and law in Ricardian England (Pennsylvania, 1999), 198-205; Rymes of Robin Hood, ed. R.B. Dobson and J. Taylor, rev. edn (Stroud, 1997); Robin Hood and other outlaw tales, ed. S. Knight and T. Ohlgren (Kalamazoo, 1997); The tale of Gamelyn, ed. W.W. Skeat (Oxford, 1884); A.P. Baldwin, The theme of government in Piers Plowman (Cambridge, 1981).
} 
that the people of Kent had been angered by false accusations made against them concerning non-payment of the poll tax. When Robert Bealknap, chief justice of the Common Bench, was sent to enquire into the situation, the commons reportedly declared he was 'maliciously proposing to undo them by the use of false inquests taken before him. ${ }^{10}$ Similarly the rebels' consistent declarations of loyalty to King Richard were contrasted with the abuses committed by local office-holders, abuses that the rebels trusted the king to resolve once they had a chance to put their complaints before him. So, for instance, the Anonimalle chronicle includes a scene in which the Kentish rebels arrive in Canterbury on 10 June, and seek out the local officials the mayor and bailiffs as well as the commons - and force them to swear to be 'faithful and loyal to King Richard and the loyal commons of England', perhaps intending this scene to underline their grievance over the corrupt practices of such officials. ${ }^{11}$ Again, on arrival at Blackheath outside London, one of their first actions was apparently to send a written petition to the king. ${ }^{12}$ Whether or not the rebels truly felt themselves to be victims of mistreatment and false accusation in the law courts, they knew that to express their grievances in this way might lend coherency to their actions, and might, crucially, encourage the king to offer them pardon for their direct action in bringing such corrupt practices to his attention. It was an idea which also found expression in the vernacular letters which circulated among the rebels; one such letter articulated the idea that justice was only available to those who could pay, and that 'true love' had fled in the face of falseness and sin:

Jack Trewman doth yow to understande that falsnes and gyle havith regned to long, and trewthe hat bene sette under a lokke, and falsnes regneth in everylk flokke. No man may come trewthe to, bot he syng si dedero. Speke, spende and spede, quoth Jon of Bathon, and therefore synne fareth as wilde flode, trew love is away, that was so gode, and clerkus for welthe worche hem wo. ${ }^{13}$

Sir Michael de la Pole was later to single out the same problem in the parliament of October 1383, citing the 'acts of disobedience and rebellion which men have recently committed ... towards the lesser servants of the king, such as the sheriffs, escheators, collectors of the subsidies and others of the same type'. ${ }^{14}$ It was a useful concept for both the Crown and the rebels, in that it brought to mind the recognised procedure for lodging such complaint through a written petition to the monarch. For the Crown it might reinforce the sense that there was a proper procedure for such complaints, a procedure which the rebels had blatantly deviated from. For the rebels, drawing parallels between their actions and the petitioning process would lend legitimacy to their cause. If, as they claimed, they were victims of false accusation in the law courts, one common method of seeking redress would be to put forward a petition for pardon. This was not to admit guilt, but rather a means of appealing to the king and council to have the case against them annulled through pardon.

\footnotetext{
${ }^{10}$ Peasants' Revolt, ed. Dobson, 125.

11 Peasants' Revolt, ed. Dobson, 127.

12 'As the king ... would not come to them, the commons of Kent sent him a petition'. (Anonimalle chronicle). Peasants' Revolt, ed. Dobson, 130.

${ }^{13}$ Peasants' Revolt, ed. Dobson, 382. Si dedero literally means 'I will give' (a payment). 'Jon of Bathon' might perhaps refer to John Bampton, the commissioner sent to investigate the non-payment of the poll tax in Essex. It has been suggested that this verse should be viewed alongside Langland's Piers Plowman. For further discussion see: Musson and Ormrod, Evolution, 172-3.

${ }^{14}$ PROME, 'Parliament of October 1383', item 6.
} 
According to the chronicles, the rebels succeeded in gaining their first audience with the king on Thursday 13 June, once they had made their way to the area around the church of St Katherine, to the east of the Tower. The Anonimalle chronicle suggests that the rebel leaders were already seeking to agree terms and the idea of pardon featured prominently in the reported dialogue. ${ }^{15}$ The insurgents requested that the king hand over the traitors in the Tower, and give them charters of manumission and pardon for all offences. In response to their request, Richard instructed a clerk to write a bill in their presence, granting them 'pardon for all manner of trespass, misprisons and felonies done up to this hour'. After sealing the document with his signet in front of them he sent two of his knights to show the bill to the people who had gathered around St Katherine's:

The king benevolently granted their requests and made a clerk write a bill in their presence in these terms: 'Richard king of England and France, gives great thanks to his good commons, for that they have so great a desire to see and maintain their king: and he grants them pardon for all manner of trespasses and misprisons and felonies done up to this hour, and wills and commands that everyone should quickly now return to his own home: He wills and commands that everyone should put his grievances in writing, and have them sent to him; and he will provide, with the aid of his loyal lords and his good council, such remedy as shall be profitable both to him and to them, and to the kingdom.' He put his signet seal to this document in their presence and then sent the said bill by the hands of two of his knights to the people around St Katherine's. And he caused it to be read to them, the man who read it standing up on an old chair above the others so that all could hear. ${ }^{16}$

The suggestion that Richard asked the rebels to send their grievances to him in writing conveys the sense that the rebels had deviated from the legitimate procedures of complaint, but also demonstrates the magnanimity of the monarch, and the implication that their complaints would be taken seriously. The claim that the rebels requested pardon from the king at this first meeting is also interesting. Among the extant petitions for pardon from the later fourteenth century, there are a significant number of cases in which the petitioner claims to have been 'maliciously indicted' by their enemies. ${ }^{17}$ There is no sense that the petitioner humbly seeks the king's grace; rather, it is the voice of indignation that resonates most strongly. Sometimes the petitioner complained that the case against them had been concocted by officers of the Crown. In one particularly convoluted case from the 1330 s a petitioner claimed that the sheriff, the sub-sheriff and the receiver of the king's writs had conspired together and paid certain men

\footnotetext{
${ }^{15}$ St Katherine's church and hospital were situated to the east of the Tower (Peasants' Revolt, ed. Dobson, 158).

16 Peasants' Revolt, ed. Dobson, 159-60.

17 Thirty-five such petitions can be identified in the ancient petitions alone. Petitioners would complain of being 'maliciously', 'falsely' or 'wrongly' indicted by their enemies. Pardons explicitly stating that they had been given on grounds of malicious indictment can also be found in the patent rolls. See: Kew, The National Archives [all subsequent references to documentary sources are to The National Archives unless otherwise specified] SC 8/2/88; SC 8/18/872; SC 18/898; SC 8/33/1635; SC 8/36/1800; SC 8/41/2026; SC 8/46/2276; SC 8/52/2586; SC 8/59/2937; SC 8/60/2979A; SC 8/67/3304; SC 8/97/4813; SC 8/112/5584; SC 8/141/7001; SC 8/151/7537; SC 8/183/9101; SC 8/183/9106; SC 8/183/9133; SC 8/193/9643; SC 8/194/9661; SC 8/201/10009; SC 8/221/11027; SC 8/227/11306; SC 8/227/11320; SC 8/228/11383; SC 8/240/11964; SC 8/242/12097; SC 8/245/12247; SC 8/252/12559; SC 8/252/12568; SC 8/253/12615; SC 8/254/12666; SC 8/260/12990; SC 8/262/13099; SC 8/268/13388; Calendar of the Patent Rolls [hereafter CPR], 1340-43, 499; CPR 1343-45, 143; CPR 1345-48, 479, 514; CPR 1350-54, 489; CPR 1354-58, 356, 43-4; CPR 1358-61, 165; CPR 1389-92, 318.
} 
to indict him of unspecified crimes. ${ }^{18}$ In 1381 , the rebels were certainly alluding to established notions of petitioning for pardon by the time they came before the king in person.

The reference to petitioning and to the charter of pardon also gives a powerful sense of the physicality of the documents, something D. Pearsall might describe as an 'authenticating touch', a detail included to give the audience a familiar frame of reference. ${ }^{19}$ Froissart, too, conjures up this allusion when he notes that on Friday 14 June the king ordered more than 30 clerks to write out charters, patents and letters of protection, which they were to issue to the rebels. ${ }^{20}$ The Anonimalle chronicle adds that no fines were taken for the sealing or transcription of these documents. ${ }^{21}$ References to such documents also established links with other contexts - the reading aloud of a pardon, for instance, would have brought to mind similar contemporary scenes of 'proving' pardons in the royal courts. Here the letter patent would be publicly exhibited and read aloud before the court, giving the opportunity for an appellant to come forward. ${ }^{22}$ If, as has been suggested here, the insurgents were attempting to portray their cause as legitimate protest against injustice, then references to procedures and legal documents familiar from the royal courts would lend authority to their actions.

A similar emphasis on the physical document can be found in the St Albans context. According to a petition presented by the Abbot, his tenants had forced him to make them charters of their own devising, for various franchises and liberties. Although they later surrendered the documents, the Abbot noted that they had made various copies through which his successors could be disseised, and asked that all such charters should be declared null and void. ${ }^{23}$ It has been noted elsewhere that the rebels displayed an ambiguous attitude towards written documents. ${ }^{24}$ In Essex they destroyed court rolls and manorial records, in Cambridge they burned the muniments of the University, and in London they ransacked administrative and legal archives at

\footnotetext{
${ }^{18} \mathrm{SC} \mathrm{8/60/2979A}$. In this case the king ordered the justices of trailbaston to review the record and process of the indictment. The man accused of ravishing Robert Martyn's wife was later pardoned and a commission of oyer et terminer was sent to investigate Martyn's actions in the matter (CPR 1338-40, 58, 352-3).

${ }^{19}$ For D. Pearsall, this particular scene exemplifies the chronicler's use of 'authentic touches' - the detail of the 'old chair' on which the clerk stands to read the bill, for example. On the one hand the chair, he says, has the air of something seen, not invented, yet on the other hand it might have been a detail included to give the 'illusion of actuality', and carries with it the impression of impropriety and indignity, a reversal of the proper order (Pearsall, 'Interpretative models', 67). It might further be added that 'old chair' is only one possible translation of the chronicler's phrase 'auncien chare', which could instead be rendered as 'old cart'. The Anonimalle chronicle, 1333-1381, ed. V.H. Galbraith (Manchester, 1970), 143. Thanks to Dr Shelagh Sneddon and Prof. Jocelyn Wogan-Browne, University of York, for their advice on this point.

${ }^{20}$ Peasants' Revolt, ed. Dobson, 192. As Mark Ormrod notes, the word 'charter' is often used generically in relation to royal grants in this period, but charters in fact had a diplomatic form distinct from letters patent. W.M. Ormrod, 'Robin Hood and the public record: the authority of writing in the medieval outlaw tradition', in: Medieval cultural studies: essays in honour of Stephen Knight, ed. R. Evans, H. Fulton and D. Matthews (Cardiff, 2006), 73, n. 33.

${ }^{21}$ Peasants' Revolt, ed. Dobson, 162-3.

${ }^{22}$ N. Hurnard, The king's pardon for homicide before AD 1307 (Oxford, 1969), 171-93; J.A. Doig, 'Political propaganda and royal proclamations in late medieval England', Historical Research, 71 (1998), 253-80; Ormrod, 'Robin Hood', 61 and n. 14.

${ }^{23}$ SC 8/20/955.

${ }^{24}$ N.P. Brooks, 'The organisation and achievement of the peasants of Kent and Essex in 1381', in: Studies in medieval history presented to R.H.C. Davis, ed. H. Mayr-Harting and R.I. Moore (London, 1985), 247-70; Ormrod, 'Government', 1-30; M. Rampton, 'The Peasants' Revolt of 1381 and the written word', Comitatus: A Journal of Medieval and Renaissance Studies, 24 (1993), 45-60; S. Justice, Writing and rebellion. England in 1381 (Berkeley, 1994). See also Grummitt, 'Cade's Rebellion', 111-12.
} 
Westminster, Lambeth Palace, the Temple and the Tower of London. ${ }^{25}$ Walsingham noted that they targeted such records and the clerks responsible for producing them: "they strove to burn all old records; and they butchered anyone who might know or be able to commit to memory the contents of old or new documents. It was dangerous enough to be known as a clerk, but especially dangerous if an ink-pot should be found at one's elbow'. On the other hand they were clearly eager to have their charters of manumission and pardon in their possession. It was even suggested that before the men of Essex returned home, they appointed several representatives to stay behind in order to obtain the king's charter. ${ }^{26}$ These references to the rebels targeting particular documents, and making their own copies of charters highlights their capacity to appropriate the structures of local administration for their own ends. ${ }^{27}$ Steven Justice has shown that the rebels articulated their complaints in vernacular idioms that were different from the conventions of royal government. But they also proposed that formal charters could be drawn up under the great seal guaranteeing them manumission and pardon. ${ }^{28}$ As Mark Ormrod notes, there was no precedent for such a document, and the king arguably had no right to issue one - but it seems the rebels assumed one could simply be invented. ${ }^{29}$

It should also be remembered that the physical document of pardon had an iconographic value, of which the rebels were well aware. The idea of royal grace as the ultimate resolution for those wrongly accused was clearly represented by the king's letters patent of pardon. Pardon was, in some instances, representative of vindication rather than of implied guilt. For the rebels it represented a direct link to the personal form of grace dispensed by their monarch, unmediated by law courts or royal officers. Indeed, the chronicle accounts emphasise the extent to which the rebels invested their hopes in a face-to-face meeting with the king. Froissart even gives the dialogue of a message purportedly sent by the rebels to the king:

Sir, the commons of your realm hath sent me to you to desire you to come and speak with them on Blackheath; for they desire to have none but you: and, sir, ye need not have any doubt of your person for they will do you no hurt; for they hold and will hold you for their

\footnotetext{
25 Peasants' Revolt, ed. Dobson, 364.

${ }^{26}$ Walsingham, Peasants' Revolt, ed. Dobson, 176.

${ }^{27}$ C. Dyer, 'The social and economic background to the rural revolt of 1381', in: The English rising of 1381, Hilton and Aston, 9-42. More generally, see: R.B. Goheen, 'Peasant politics? Village communities and the Crown in fifteenth-century England', American Historical Review, 96 (1991), 42-62; I.M.W. Harvey, 'Was there popular politics in fifteenth-century England?', in: The McFarlane legacy. Studies in late medieval politics and society, ed. R.H. Britnell and A.J. Pollard (Stroud, 1995), 155-74.

${ }^{28}$ Justice, Writing and rebellion, 13-66, 140-92. For the vernacular letters which apparently circulated among the rebels, see: Peasants' Revolt, ed. Dobson, 381-3. For their suggestion that particular charters could be drawn up, see: Peasants' Revolt, ed. Dobson, 159-63; B.F. Harvey, 'Draft letters of manumission and pardon for the men of Somerset in 1381', English Historical Review, 80 (1965), 89-91. Several legal cases from the later fourteenth century refer to forged charters of pardon, see, for, example, Select cases in the court of King's Bench, ed. G.O. Sayles, 8 vols (Selden Society 55, 57, 58, 72, 74, 76, 82, 88, London, 1936-71), vol. 3, 149-52. The permeation of legal knowledge has also been examined in: C.J. Neville, 'Common knowledge of the common law in later medieval England', Canadian Journal of History, 29 (1994), 461-78; A. Musson, 'Social exclusivity or justice for all? Access to justice in fourteenthcentury England', in: Pragmatic utopias. Ideals and communities, 1200-1630, ed. R. Horrox and S. Rees-Jones (Cambridge, 2001), 136-55.

${ }^{29}$ Ormrod, 'Robin Hood', 63. In the parliament called in the autumn of 1381, the Lords were to question the right of the Crown to issue charters of manumission, but its right to bestow royal mercy on its subjects was never in doubt. PROME, 'Parliament of 1381', item 13. The Lords reminded the king of their property rights over serfs. Tuck emphasises that only the king could release men from the obligation to observe due process of law in depriving even rebels of their lives (Tuck, 'Nobles, commons', 199-200).
} 
king. But, sir, they say they will shew you divers things, the which shall be right necessary for you to take heed of. ${ }^{30}$

The rebels had already made the familiar accusations of corruption against royal agents. This conventional rhetoric of the 'evil councillor' trope has been noted elsewhere, as a longstanding means of criticising government without voicing treasonous condemnation of the king himself. ${ }^{31}$ The idea of corruption among the king's officers in the localities, the gentry justices, escheators and their like, was a related and similarly familiar concept, the staple of outlaw tales like the Gest of Robin Hood and the Ballad of Adam Bell. ${ }^{32}$ Once the king was made aware of the honourable outlaws' plight he would see the justice of their cause and pardon them for resorting to direct action. It might also be true to say that the rebels in 1381 believed that their best chance stood in putting their case before the king and asking for his pardon. Nigel Saul suggests that the rebels hoped Richard would prove an ally if released from the control of his councillors. ${ }^{33}$ But in their desire for pardon they were also expressing a longstanding and consistent view that royal mercy represented a direct link between the king and his subjects. While it is true that the monarch did not personally oversee the several hundred letters of pardon issued every year, it is possible that the rebels still viewed a pardon as a personal link to royal grace. ${ }^{34}$ As Alan Harding has argued, Wat Tyler's reference to the 'law of Winchester' at the Smithfield meeting perhaps alluded to a similar ideal. ${ }^{35}$ The 1285 statute had become a touchstone of the principle of community self-policing - the hue and cry acting with the authority of the Crown, without the intervention of the sheriffs and gentry justices. As Harding suggests, it is possible that the rebels looked back to an idealised situation in which the king exercised exclusive lordship, with a small number of central justices, and received the written complaints of individuals and local communities in his court of parliament. The intervening years had seen the steady encroachment of gentry justices at the local level, and special criminal commissions in the hands of the magnates. The rebels therefore perceived a shift in judicial authority which had "changed the social groups in whose interests the law worked. ${ }^{36}$ It seems possible that the rebels petitioned for pardon as a means of bringing their complaint to

\footnotetext{
${ }^{30}$ Peasants' Revolt, ed. Dobson, 142. See also the Anonimalle chronicle, in Peasants' Revolt, ed. Dobson, 129-30.

31 Tuck, English Nobility, 43; J.A. Tuck, 'Richard II's system of patronage', in: The reign of Richard II. Essays in honour of May McKisack, ed. F.H. Du Boulay and C.M. Barron (London, 1971), 5-6; Ormrod, 'Government', 29-30.

${ }^{32}$ Gest of Robyn Hode, 11. 1645-58. Adam Bell, 11. 435-526. The texts are published in: Robin Hood and other outlaw tales, ed. Knight and Ohlgren. For further discussion see Ormrod, 'Robin Hood', 67-9.

33 Saul, Richard II, 76.

34 A Year Book entry of 1329 describes how a trial judge would recommend pardon, and the chancellor would then certify the issue of the writ from chancery without the need to consult the monarch. Sir Anthony Fitzherbert, La graunde abridgement collect par le iudge tresreuerend Monsieur Anthony Fitzherbert (London, 1565), 'Corone et plees del corone,' f. 257v (361). However, it was still possible for a petitioner to appeal to the king's grace for pardon, without having any formal legal grounds on which to base the request. In several petitions the supplicant admits to wrongdoing, but asks for pardon on the grounds of long and loyal service to the Crown, usually as a soldier or as a member of the royal household, SC 8/69/3426; SC 8/127/6317; SC 8/238/11898. The need to gain an audience with the king himself seems to have been important to some petitioners - in 1410 Margaret Chamber of Norwich petitioned for pardon and made a point of asking that the royal porters be ordered to permit her free entry before the monarch, SC 8/255/12707.

35 Peasants' Revolt, ed. Dobson, 164; A. Harding, 'The revolt against the justices', in: The English rising of 1381, ed. Hilton and Aston, 165-93; A. Musson, Medieval law in context. The growth in legal consciousness from Magna Carta to the Peasants' Revolt (Manchester, 2001), 250-2.

${ }^{36}$ Harding, 'Revolt against the justices', 168.
} 
the king himself, and of ensuring the case against them was annulled, a process which they viewed as exemplifying the ideal judicial relationship between the king and his commons. ${ }^{37}$

Of course, in marching on London with 'force and arms' and demanding an audience with the king, the rebels were themselves subverting the judicial process for their own ends. ${ }^{38}$ However, as John Watts has suggested, Wat Tyler and his company saw themselves as representatives of that broad, yet elusive group evoked by the term 'commons', and adopted the role of 'public petitioners', with implicit political rights. ${ }^{39}$ It has been noted before that their grievances and the political expectations they expressed were not exclusive to the lower social orders. ${ }^{40}$ Similarly, in drawing on notions of pardon, they dealt in a shared language, familiar to all ranks of society. In the same way that the rebels alluded to the 'evil councillor' topos, and with it to a whole genre of political discourse created over the last century, so too, the idea of royal grace as a pure form of justice was echoed in a range of texts, from the work of Gower to poems such as the Outlaw's song of Trailbaston in the complaint tradition and to Corpus Christi plays like the Killing of Abel. ${ }^{41}$

It is also important to note that the idea of pardon belonged as much to the government in 1381 as it did to the rebels. In drawing on the notion of royal mercy as an answer to a violent protest of this kind, the Crown was able to downplay the extent and novelty of the challenge presented by the rebels. Their complaints could be dealt with through established methods of political reconciliation: as the followers of the Ordainers in 1313 or those involved in the 1327 coup had been granted amnesty, now the pardon could be extended down the social order to the insurgents of $1381 .^{42}$ Indeed, if we return to the chronicle accounts of the revolt, there is the suggestion that the government had begun to discuss a possible grant of mercy as soon as it was known that the insurgents were massing outside the city. Froissart gives an account of an emergency meeting held in the Tower on the evening of 13 June. ${ }^{43}$ He suggests that some of those present favoured a military riposte to the rebels, the mayor putting forward a plan to leave the Tower under cover of darkness and enter the city, 'so to slay all these unhappy people, while they were at their rest and asleep'. He suggested that they could call on others who lived in the

\footnotetext{
37 Alan Harding suggests that Wat Tyler's demands stand in a tradition of debate between the king and the people on the proper administration of justice - a debate which had been aired in parliament 18 months before the revolt. Harding, 'Revolt against the justices', 174.

${ }^{38}$ References to the rebels using 'force and arms', being 'arrayed as if for war' and raising banners, brought to mind the precise definition of treasonous activity outlined in the Treason Law of 1352. J. G. Bellamy, The law of treason in England in the later middle ages (Cambridge, 1970), 103-5, 143, 183, 207.

${ }^{39} \mathrm{~J}$. Watts, 'The pressure of the public on later medieval politics', in: The fifteenth century IV: political culture in late medieval Britain, ed. L. Clark and C. Carpenter (Woodbridge, 2004), 161.

${ }^{40}$ G.L. Harriss, 'Political society and the growth of government in late medieval England', Past \& Present, 138 (1993), 56; W. M. Ormrod, Political life in medieval England, 1300-1450 (Basingstoke, 1995), 56-8. See also C. Valente, The theory and practice of revolt in medieval England (Aldershot, 2003), 3-4, 167-70.

${ }^{41}$ J. Gower, Confessio amantis, ed. R.A. Peck (New York, 1958), book 7, 11. 3103-17; Rymes of Robin Hood, ed. Dobson and Taylor, 253; The Wakefield pageants in the Towneley cycle, ed. A. C. Cawley (Manchester, 1958); Watts, 'Pressure of the public', 168-9.

${ }^{42}$ For 1313 see: Foedera, conventions, literae et cujuscunque generic acta publica, ed. T. Rymer (London, 1704-35), vol. 2, 230-3; CPR 1313-17, 21-6; Thomas Walsingham, Historia Anglicana [hereafter HA] ed. H.T. Riley (Rolls Series 28, 1863-64), vol. 1, 136; E.A. Roberts, 'Edward II, the Ordainers and Piers Gaveston's jewels and horses, 1312-1313', Camden Miscellany, 15 (1929), 16. In 1327, Edward granted amnesty to all those who had taken illegal action in the coup: see: $C P R$ 1327-30, 43-57, 115-23. A further 234 were given pardon on condition that they joined the forthcoming expedition against the Scots, $C P R$ 1327-30, 110-13, 161-3. 175 of those who had held Caerphilly castle against the king and queen were also pardoned, $C P R$ 1327-30, 13, 37-9.

${ }^{43}$ Peasants' Revolt, ed. Dobson, 189-90; Saul, Richard II, 66-80.
} 
city to support them, in particular Sir Robert Knolles, who was guarding his lodging with a force of more than 120 men. However, Froissart reports that several others present feared that military action would provoke the rest of the commons of London to rise in rebellion. The earl of Salisbury supposedly articulated this view when he advised the king, 'if you can appease them with fairness, it were best and most profitable, and to grant them everything that they desire, for if we should begin a thing the which we could not achieve, we should never recover it again, but we and our heirs ever to be disinherited'. Froissart's account here gives a sense of continuity, from Salisbury's counsel to the king's proclamation to the rebels that he would pardon them all their different offences. ${ }^{44}$ When this was not enough to halt the violence the council persevered with mediation. After discussing the matter early on Friday morning they decided that the king should meet the rebels at Mile End later the same day. ${ }^{45}$ It was at this meeting that Richard agreed to issue the famous charters of manumission to the insurgents, which have been the focus of so much scholarly debate. ${ }^{46}$ However, less attention has been paid to the hastily drafted general amnesty which was also proclaimed: the king pardoned his subjects for all felonies and acts of treason they had performed. ${ }^{47}$ Walsingham states that the terms of this charter were confirmed to the rebels the next day at Smithfield, and again at Clerkenwell, and this, coming after the death of their leader Wat Tyler, was enough to persuade them to disperse and return to their homes. $^{48}$

What do these references to reconciliatory overtures on the part of the Crown amount to? One line of argument would be to say that the promise of pardon was a cynical means of placating the rebels and encouraging their dispersal from the capital, so that the Crown could then initiate its favoured policy of repression. This seems to be supported by the revocation of the charters of manumission on 2 July. ${ }^{49}$ For the author of the Anonimalle chronicle such references could be used to suggest that the young king himself took the initiative in placating the rebels, in the absence of any leadership from his councillors. ${ }^{50}$ In this sense it fits into the chronicler's broader objective of promoting Richard's own role in saving the day. The association of the king himself with the policy of conciliation seems to have been in the mind of the chronicler, if not also the royal advisers. The narrative of events suggests that

\footnotetext{
${ }^{44}$ Peasants' Revolt, ed. Dobson, 159, 190.

45 Peasants' Revolt, ed. Dobson, 190.

${ }^{46}$ Harvey, 'Draft letters', 89-91; E.B. Fryde, Peasants and landlords in later medieval England (Stroud, 1996), 39-53; R.H. Hilton, Bond men made free (London, 1973), 224; Dyer, 'Social and economic background', 9-42; Dunn, Great rising, 96-7.

${ }^{47}$ Ambiguity exists over whether Richard issued the charters at Mile End, or whether he simply agreed to have them drawn up, and actually issued them at Smithfield. Froissart clearly states that letters were given on the same day as the Mile End meeting (Peasants' Revolt, ed. Dobson, 192), but Walsingham believed that no charter was delivered to the rebels before the meeting at Smithfield. The only copy of the text is that transcribed by Walsingham (Peasants' Revolt, ed. Dobson, 180-1). Three of the letters issued to specific counties were recorded: Walsingham transcribed the letter for Hertfordshire (Peasants' Revolt, ed. Dobson, 275); the letter for Kent is in London, British Library, Cotton Charter 4, 51; and a draft drawn up by the men of Somerset is published in Harvey, 'Draft Letters', 90. According to Harvey no warrant for any has been found, although even on 15 June the king gave warrants for some conciliatory measures: C 81/471/1833 contains a warrant for letters patent issued to the mayor of Oxford (later cancelled, CPR 1381-85, 16). 48 Peasants' Revolt, ed. Dobson, 177, 180.

49 Revocation dated 2 July. HA, vol. 2, 20-2; Thomas Walsingham, Chronicon Angliae 1328-1388 [hereafter CA], ed. E.M. Thompson (Rolls Series 64, 1874), 318. The revocation was confirmed in the November parliament: PROME, 'Parliament of 1381', item 13; Statutes of the Realm, 1101-1713 [hereafter SR], ed. A. Luders, 11 vols (Record Commission, London, 1810-28), vol. 2, 20.

${ }^{50}$ Peasants' Revolt, ed. Dobson, 159; Saul, Richard II, 67-8.
} 
Richard ordered the pardon to be proclaimed in front of the rebels himself, and that he sealed the charter with his own signet - a seal normally used to communicate the king's personal orders to his chancery office, and to warrant their issue of a charter under the great seal. ${ }^{51}$ There is perhaps something to be said for the fact that the grant of royal grace allowed the governing elite to claim a leading role for the young king. Accordingly the pardon had the seal of royal authority and thus stressed the reciprocal obligation on the part of the king's subjects. It also acknowledged the active role of the monarchy in guaranteeing their rights. The grant of a pardon perhaps allowed Richard's ministers to present the king at the head of the response, while still retaining control of policy. ${ }^{52}$ Walsingham also includes a scene in the wake of the Smithfield meeting, when the knights surrounding the king request permission to decapitate 'at least one or two hundred of the criminals as a warning to posterity'. But, according to the chronicler, the king refused them the request, saying that 'many of the commons had followed the mob out of fear; if he assented to the proposal, it might well be that the innocent would be punished and the guilty escape unharmed. ${ }^{53}$ This recognition of the dangers of condemning the innocent along with the guilty chimed with later protests put forward by the parliamentary Commons (discussed below). The scene clearly bestowed on the young king the sense of fairness and equity required of an adult medieval monarch. Froissart's details on the meetings in the Tower also give the impression that the council were able to contemplate the idea of reconciliation, although they had not decided whether negotiations with the rebels should be binding. ${ }^{54}$

The question of sincerity aside, it is interesting that the chroniclers did allow for ideas of mercy to be associated with the young king from the early stages of their narratives. While it is true that for writers such as Walsingham the idea of the violation of divinely inspired social hierarchy was the dominant frame of reference, it is clear that the chroniclers also wove into their accounts the model of royal mercy. ${ }^{55}$ Moreover, the Crown and commons shared this common language of pardon, and understood that it signified a particular relationship between the king and his subjects. By the beginning of October, letters of pardon began to be issued from chancery. It is worth noting from the outset that the Crown had sanctioned the issue of these letters only a few months after the insurrection. Importantly, these moves were made before parliament had convened and therefore before the parliamentary Commons had a chance to express their views on the matter.

\footnotetext{
${ }^{51}$ Richard's use of the privy seal in this context might signify that the document he was holding up to the rebels was intended to be a warrant, which would later be sent to chancery to authorise the issue of individual charters to the rebels under the great seal. This is supported by references in Froissart's account and in the Anonimalle chronicle, to chancery clerks being ordered to write out large numbers of charters, patents and letters of protection. See note 20 above.

${ }^{52}$ Musson and Ormrod, Evolution, 170. Letters patent on the pardon roll were warranted 'by the king in parliament', referring to the November 1381 ordinance, or 'by the king and council', suggesting Richard was still expressing his authority only in association with his advisors. In 1380 plans had been aired for the king to lead an overseas military expedition. Watts mentions a similar proposal for Henry VI to head the Calais army: J. Watts, Henry VI and the politics of kingship (Cambridge, 1996), 130, and n. 24. This suggests that both administrations sought to demonstrate the leadership, although not the coming of age of the king.

${ }^{53}$ Peasants' Revolt, ed. Dobson, 180. The suggestion that some participants had been forced to follow the rebels was echoed in later judicial proceedings. See, for example, the case of Osbert de Mundford in Norfolk, who was forced to join the rebel contingent under the leadership of John Gelder. KB 9/166/1, mm. 53, 78. Discussed in H. Eiden, 'Joint action against 'bad' lordship: the Peasants' Revolt in Essex and Norfolk', History, 83 (1998), 9.

54 Saul, Richard II, 68.

55 Pearsall, 'Interpretative models', 64-5; Peasants' Revolt, ed. Dobson, 367-72.
} 
The debate surrounding the nature of the government reaction in the weeks after the revolt has centred on the judicial commissions sent into the Home Counties, and the numbers of rebels executed as a result of these proceedings. ${ }^{56}$ One source that has been somewhat overlooked in this scholarship has been the chancery pardon roll. As the name suggests, this roll recorded the recipients of pardon in the wake of the revolt. ${ }^{57}$ Not all recipients of pardon listed in the roll were actually involved in the rebellion, and therefore the roll does not necessarily help to identify prominent rebels. ${ }^{58}$ Despite this, the pardon roll is of some use for a number of reasons. At the most basic level, the very creation of a new supplementary roll suggests an early assumption that the Crown would authorise the issue of pardons in significant numbers, and that an accurate record needed to be kept. A separate pardon roll was only created on three other occasions in the fourteenth century; one for the pardons issued for a military campaign of the early 1340s, one for the pardon celebrating Edward III's jubilee year in 1377, and a third at the end of Richard II's reign, which related to his dealings with the Appellants. ${ }^{59}$ The roll is also useful in highlighting the continuity between the themes present in the narrative sources discussed above, and the administrative and legal records, so often treated entirely separately.

The first entries on the roll demonstrate that pardons began to be issued soon after the revolt. The very first was issued on 22 July, but this seems to be an exceptional case. ${ }^{60}$ The next pardon was issued on 18 October, and was followed by 114 others over the next month alone. In total the pardon rolls associated with the Peasants' Revolt contain close to 3500 names. ${ }^{61}$ However this first group of 115 pardons issued in October and November 1381 seem to form a discreet group on the roll. The wording of the pardon in these cases is different from all subsequent pardons, and crucially they were

\footnotetext{
56 See note 2 above.

${ }^{57}$ C 67/29. Separate 'pardon rolls' were only created at times of high demand, otherwise they would simply be recorded on the main series of patent rolls. The 'pardon rolls' were archived as part of the TNA class C 67, termed 'supplementary patent rolls'. This series also includes letters of protection and safe-conduct for those on the king's service and appointments of mayors of the staple and commissions of the peace. They range in date from 1275-1749. It is also worth noting that in the aftermath of the Peasants' Revolt, there was some duplication of names between the pardon roll and the main patent roll - Prescott suggests that this is because a petitioner might pay to have another record of their pardon entered on the main roll. Prescott, 'Judicial Records', 355.

${ }^{58}$ See below for further discussion. The task of identifying individual members of the rebel band has been undertaken by several scholars, see: Prescott, 'Judicial records'; Eiden, 'Joint action'; Hilton, Bond men; Dyer, 'Social and economic background'; C. Dyer, 'The rising of 1381 in Suffolk: its origins and participants', Proceedings of the Suffolk Institute of Archaeology and History, 36 (1988), 274-87; A. Prescott, 'London in the Peasants' Revolt: a portrait gallery', London Journal, 7 (1981), 125-43. Prescott suggests that the pardon roll is overrated as a source of information about the revolt (Prescott, 'Judicial records', 334). He also points out that the list of exclusions from the general pardon (PROME, 'Parliament of 1381', item 63) is not a reliable guide to the identity of leading insurgents (Prescott, 'Judicial records', 361).

${ }^{59}$ C 67/28A, 28B, 29, 30, 31. Discussion of the last two can be found in: W.M. Ormrod, "Fifty glorious years": Edward III and the first English royal jubilee', Medieval History, new series, 1 (2002), 13-20; H. Lacey, “"Mercy and truth preserve the king": Richard II's use of the royal pardon in 1397 and 1398', in: Fourteenth Century England IV, ed. J.S. Hamilton (Woodbridge, 2006), 124-35.

${ }^{60}$ This pardon, and one other issued at the beginning of October appears, in the main patent roll. Paul Salesbury: C 66/311, m. 31; CPR 1381-85, 30-1; Peasants' Revolt, ed. Dobson, 228; Thomas de Wycresley: CPR 1381-85, 43. For further discussion of Salesbury's role, see Dunn, Great rising, 65 and Prescott, 'Judicial records', 350.

${ }^{61}$ There are 115 names on the first three membranes of the roll (C 67/29, mm. 41, 40, 39). In total, 2253 pardons were issued before October 1382. At this point the benefits of the amnesty were extended to all the king's subjects, free of the requirement to sue out a letter of pardon. Even so, a further 588 names were added to the roll as receiving pardon, from May 1383 until the end of the reign. This gives a total on the roll of 3429 .
} 
issued before parliament had met to sanction a pardon. It was not, in fact, until 13 December 1381 that parliament drew up a standard form of pardon for involvement in the rebellion. These early pardons are also different from the ones that followed because of the widely varying amount that recipients paid for them. One column on the roll gives the assessed value of each person's possessions, and the fine they were to pay into the hanaper. Normally, a pardon would have cost $18 \mathrm{~s} .4 \mathrm{~d}$. However, payments for these pardons varied considerably. Most were between 25s. and 30s., but some were far higher: two men paid as much as $£ 40$. At the other end of the scale one man was granted pardon free of any fine. ${ }^{62}$ After the pardon was issued by parliament, the price was fixed at $16 \mathrm{~s} .4 \mathrm{~d}$., until a later proclamation made it free to all those who wanted one. ${ }^{63}$

This raises the question of who these early recipients were. Herbert Eiden noted that not everyone who bought a pardon can be proved to have been involved in the insurgency. ${ }^{64}$ This in itself is surely interesting; that people were buying pardons as a form of insurance against the possibility of malicious indictment, a concern which, according to certain of the chroniclers, had been prevalent since the early stages of the revolt. ${ }^{65}$ Prescott also points out the inconsistencies in the issue of pardons, drawing his evidence from Walsingham's account of the St Albans' trials. Walsingham gives details of the execution of leading insurgents, men like William Grindcobbe and William Caddington. Yet, another leading St Albans rebel, Richard Wallingford, was one of the first to receive pardon. According to Walsingham, the judicial sessions held in the town throughout October by Chief Justice Tresilian resulted in the execution of 15 people and the imprisonment of a further 80 men. ${ }^{66}$ However, we can add to this picture the 44 pardons granted to inhabitants of Hertfordshire by the end of November 1381, 10 of whom were residents of St Albans. Eleven of these recipients later proved their pardons in King's Bench. ${ }^{67}$ Looking just at the recipients of these early pardons, then, there does seem to be a considerable range of people. A few were leading rebels, and for them to pursue a pardon was clearly a prudent course of action, so well-known were they in the local area. In St Albans, for example, Richard Wallingford and Edmund Cook were known to be leading rebels, and both were quick to seek out a pardon. ${ }^{68}$ Similarly Geoffrey Cobbe played

\footnotetext{
${ }^{62}$ Geoffrey Cobbe and John Refham both paid $£ 40$ (C 67/29, m. 41). In Cobbe's case, the recognisance he made to pay the sum in the hanaper is noted in the close rolls, $C C R$ 1381-85, 92. William Punchon of Dartford was granted pardon without fine (C 67/29, m. 41).

${ }^{63}$ The writ for proclamation of the 1381 pardon stipulates that a pardon could be procured 'for payment only of the fee for the great seal' (CPR 1381-85, 105). This therefore indicates that the price stood at $16 \mathrm{~s}$. $4 \mathrm{~d}$. (without the $2 \mathrm{~s}$. usually payable to the chancellor). The pardon was declared free of charge in October 1382: $S R$, vol. 2, 29-30. Discussed further below.

${ }^{64}$ Eiden, 'Joint Action', 8-9.

65 See above.

${ }^{66}$ Prescott, 'Judicial records', 350-1; Walsingham, HA, vol. 2, 35-8. See Dunn, Great rising, 139-41.

${ }^{67}$ C 67/29, mm. 41-39; KB 27/482 rex, mm. 26, 26d, 27, 27d, 28, 37 (Pardons granted to inhabitants of Cambridgeshire, Northamptonshire, Yorkshire and Kent were also proved in King's Bench: KB 27/482, m. 47; KB 27/483, m. 27d; KB 27/486, m. 15; E 153/530, mm. 9-17).

${ }^{68}$ C 67/29, mm. 41, 40; Walsingham, HA, vol. 1, 475 and Appendix B, 394. Two other St Albans men were well-known rebels, and were both quick to seek pardon: John Tyler was indicted for burning the house ("called le Thwethonerhous') of the abbot, and John Garlek of freeing prisoners from the abbey and accompanying Walingford in marching on the abbey 'arrayed for war' with the banners of St George and demanding to speak to the abbot. Tyler received an early pardon on 23 October (C 67/29, m. 40) and later proved the pardon in King's Bench (KB 27/485, mm. 33, 33d). Garlek received his pardon on 20 October (C 67/29, m. 39) and again proved it in King's Bench (KB 27/482, m. 28). These events are described by Walsingham: Thomas Walsingham, Gesta abbatum monasterii Sancti Albani, ed. H. T. Riley, 3 vols (Rolls Series 28, London 1867-69), vol. 3, 301-2, 304-5. See also A. Réville, Etude sur le Soulèvement de 1381 dans le Comtés de Hertford, de Suffolk et de Norfolk (Paris, 1898), 13, 17, 18, 33, 152.
} 
a leading part in the rebellion in Cambridge, and had already been indicted by the time he received his pardon on 20 October. ${ }^{69}$ Again, Richard Denarston was one of the leading Suffolk insurgents, and got his pardon on 23 October. ${ }^{70}$ These four men were also among the wealthiest on the list. Denarston's goods were valued at $£ 6$, Wallingford was assessed at over $£ 13$, Cook at $£ 20$ and Cobbe at over $£ 28 .{ }^{71}$

Another of the wealthiest on this list was Richard Martyn of Cambridge, assessed at over $£ 20$. He received his pardon on 23 October 1381, but in his case it was recorded again in the main patent roll the following year, with the note that it was granted at the special request of Queen Anne. Seeking a pardon in his case was prudent; later, on 24 May 1382, a judicial commission was sent to Cambridge to investigate the complaint of the master of Corpus Christi College. Interestingly, the complaint was framed in terms familiar from the chronicle accounts of the rebels and their activities; the master accused Martyn and several others of breaking into the college close, having first proclaimed that the townsfolk should come to the college and help them to destroy it. They were then said to have carried away timber, doors and windows, books and jewels. They also tore up charters, assaulted the servants and hunted for the master and scholars, threatening to kill them. The call to the townsmen for support, and the targeting of charters were both common themes in narratives of the rising. ${ }^{72}$

A few of those receiving pardons in October and November had definitely already been indicted at the judicial sessions held in the Home Counties in July. ${ }^{73}$ They had a clear incentive to secure pardon as quickly as possible. Among the men indicted in the Rochester hearings before Thomas Holand, the king's half-brother, was Richard Poser. He was accused, again in terms common to chronicles and to petitions, of burning records and harassing officers of the Crown, in this instance the escheator of Kent, but was able to secure a pardon by November. ${ }^{74}$ Also in Kent, John Wryde had been accused of extorting money from two men of Canterbury and William Brown of killing two men in Maidstone. Both had received a pardon by November. ${ }^{75}$ In Norfolk three men, Richard Denarston of Suffolk (discussed above), Robert Herde of Toft Monks in Norfolk and William Metfeld of King's Lynn, were indicted before William de Ufford, Earl of Suffolk, whose commission had been sent to

maintain the peace in Norfolk and Suffolk to proclaim that all those innocent of the recent levies and gatherings there, or who were forced to join them, be in peace, but that those who continue to adhere to such levies and gatherings shall be dealt with by the best and

\footnotetext{
${ }^{69}$ Cobbe's indictment is transcribed in: E. Powell, The rising in East Anglia in 1381 (Cambridge, 1896), 137. Cobbe received his pardon on 20 October, and by 24 October the king had ordered that his confiscated lands be restored to him: CCR 1381-85, 14.

${ }^{70}$ Réville, Soulèvement, 78, 123. See below, note 76.

${ }^{71}$ C 67/29, mm. 41, 40.

${ }^{72}$ It is also worth noting that another of the men accused by the master of involvement, Robert Brigham, was also among the first to receive a pardon, and in this case he was not wealthy - the value of his goods was assessed at just over 2s. C 67/29, m. 41; CPR 1381-85, 143, 203. See below, note 81.

${ }^{73}$ For a list of references to the surviving original commission records see Prescott, 'The hand of God', 325 , n. 40.

${ }^{74}$ The Peasants' Rising and the Lollards, ed. E. Powell and G. M. Trevelyan (Cambridge, 1899), 6 (transcription of the indictment). C 67/29, m. 41.

${ }^{75}$ C 67/29, mm. 41, 40; W. Flaherty, 'The great rebellion in Kent of 1381 illustrated from the public records', Archaeologia Cantiana, 3 (1860), 71 (transcription of the indictments in JUST 1/400).
} 
speediest ways and means; and to put down, repel, resist, do justice upon and punish them, according to the law and their discretion. ${ }^{76}$

As Herbert Eiden notes, we cannot assume these men were rebels from the indictment and the pardon alone; they might have been victims of malicious indictment. Indeed, he notes that some prominent victims of the rebels procured pardons: John Butterwick, under-sheriff of Middlesex, and the knight Andrew Cavendish in Suffolk, a relative of the murdered chief justice, both bought pardons although they took no part in the rebellion. ${ }^{77}$ False indictment, as has already been noted, was a widespread concern. The burgesses of Scarborough were even moved to petition the king and request that individuals falsely indicted before the Earl of Northumberland be pardoned. ${ }^{78}$

Several more of the recipients of early pardons were to come before King's Bench in the months after they received pardon. ${ }^{79}$ The court of King's Bench had not been in session on the days when the insurgents had occupied the capital. It had been due to reopen for Trinity term on 17 June, but the revolt forced its postponement until Michaelmas term. When it did open, in the second week of October, one of its main functions seems to have been the processing of pardons. ${ }^{80}$ Three men in Cambridge, for example, had been indicted in July, but the record of their case was postponed into King's Bench and did not come before the justices until Trinity term, in the summer of 1382 , by which time the men had secured pardons. ${ }^{81}$ Another two men, Jordan de Bladington and Robert Draper, had been named as rebels in the Kent sessions of September 1381 by another suspected rebel, who had turned approver and had given the justice their names. ${ }^{82}$ One man, Stephen Sunday of Hackney, had been accused on 20 July 1381, of misdeeds at the house of the Treasurer, Robert Hales, at Highbury. Again, his case was revoked into King's Bench, perhaps because of its high profile, and it was not finally resolved until November $1384 .{ }^{83}$ On occasion it was noted in the record that the court had not yet been advised to allow a charter of pardon. This occurred when William Chaundler of Prittlewell in Essex came before King's Bench in Michaelmas term 1381. The date of his appearance in court was given as 21 November, and from the pardon roll it appears that he secured his letter of pardon two days

\footnotetext{
${ }^{76} \mathrm{~KB} 9 / 166 / 1, \mathrm{~mm} .15,22,39,41,51,64,65$. The commission's records had been returned into chancery, and then to King's Bench in pursuance of a mandamus dated 13 May 1382 (m. 1). C 67/29, m. 41. H. Eiden, 'In der Knechtschaft werdet ihr verharren ...': Ursachen und Verlauf des englischen Bauernaufstands von 1381 (unpublished Ph.D. thesis, Trier, 1995), 327, gives details of the 'Geledere-Metfeld group' and their activities in this area.

${ }^{77}$ Eiden, 'Joint action', 9.

${ }^{78}$ SC 8/139/6949.

${ }^{79}$ Of the 115 recipients of 'early' pardons, 23 have been identified in the King's Bench rolls: KB 27/482, mm. 15, 26, 26d, 27, 27d, 28, 29d, 31d, 32d, 34, 36, 37, 37d, 39, 43d, 46d; KB 27/483, m. 23d; KB 27/485, mm. 18, 27, 27d, 28d, 33, 33d; KB 27/486, mm. 11, 27. See also Réville, Soulèvement; Eiden, 'Knechtschaft'.

${ }^{80}$ Many of these represent the processing of outstanding indictments from juries in the localities. Prescott notes that King's Bench records comprise a very late stage in the proceedings against the rebels, and consist largely of the formal processing of pardons. Prescott, 'The hand of God', 325. Ormrod, 'Government', 8.

${ }^{81}$ Robert Brigham, John Refham and John Stamford. KB 27/485, mm. 27, 27d. Brigham and Refham presented two letters of pardon each before King's Bench, both purchased on the same days - 24 February 1382 and 20 October 1381 (C 67/29, mm. 41, 28). They had also both secured letters of protection dated 6 July 1382, and submitted these before the court. KB 27/485, mm. 27, 27d. The escheator of Cambridge was later ordered to restore to them their confiscated lands. CCR 1381-85, 169. Stamford secured pardon on 4 November 1381, and a letter of protection the following October. C 67/29, m. 39, Réville, Soulèvement, 242.

${ }^{82}$ KB 27/482, m. 36. C 67/29, m. 40; Réville, Soulèvement, 205.

${ }^{83} \mathrm{~KB} 27 / 494, \mathrm{~m}$. 32d. Sunday was named on the list of those to be excluded from royal grace in the 1381 parliament. Réville, Soulèvement, 209-10.
} 
later. It seems the justice was prepared to accept that the pardon was on its way, and William was dismissed after finding men willing to guarantee his appearance at a later date. ${ }^{84}$

From the King's Bench records, it becomes clear that there were several distinct groups among the men who were able to secure the first pardons. Some were implicated in specific incidents of rebellion. One group already mentioned from Cambridge was accused of rioting, extorting money and making threats against the master and scholars of Corpus Christi College. ${ }^{85}$ Three groups from Hertfordshire sought out pardons. One group, from Tring, had been indicted for involvement in forcing entry into the archbishop of Canterbury's manner and destroying records, as well as parading banners of St George, and making proclamations in the town. ${ }^{86}$ One group from Cheshunt, were accused of rebellion in nearby Waltham Cross. ${ }^{87}$ Another group were from St Albans, accused of attempting to take the records of the abbey. ${ }^{88}$ Another contingent came from Kent, indicted for breaking into the houses of prominent townsmen alongside the well-known rebel Abel Ker. ${ }^{89}$ A final group came from London, among them William Trewman, accused of attacking the former mayor Sir Nicholas Brembre. ${ }^{90}$

Yet the majority of people on the list do not seem to have been indicted before receiving pardon (although we are lacking the records for Hertfordshire). In fact only 40 of the 115 names on the list of early pardons appear in court records, chronicle references, or the parliamentary list of those excluded from grace. ${ }^{91}$ People who had not been indicted were perhaps prompted to buy pardons after seeing the judicial commissions at work. Given the relative wealth of some of those on the list, one other possibility might be that these were men who wanted to safeguard themselves against charges of not having done anything to quell the rising, or of having taken matters into their own hands and seeking revenge on some of their attackers after the suppression. ${ }^{92}$ Another

\footnotetext{
${ }^{84}$ J. Sparvel-Bayly, 'Essex in Insurrection, 1381', Transactions of the Essex Archaeological Society, new series, 1 (1878), 214-15. C 67/29, m. 41.

85 This group included Robert Brigham, John Refham, Richard Martyn and John Stamford. See also: 'The Peasants' Revolt of 1381 as it affected the villages of Cambridgeshire', in: Documents relating to Cambridge villages, ed. W.H. Palmer and H.W. Saunders (Cambridge, 1926), 36.

${ }^{86}$ Richard Horsman junior was indicted before King's Bench - KB 27/486, m. 27; Réville, Soulèvement, 39. Three other men from Tring also bought early pardons: William Tyngewyk, Walter Smyth and Richard Mathewe, C67/29, m. 41.

${ }^{87}$ Walter Parchemer came before King's Bench - KB 27/482, m. 43; Réville, Soulèvement, 38. Thirteen other men from Cheshunt bought early pardons: Walter Ferrour, Richard Dalowe, Simon atte Marche, Thomas Ferrour, Gamelin Impey, Thomas Swetefote, William Carles, William Bisshop, Walter Lavendar, John Couper, William Phippe, John Everard, Thomas Cut, C 67/29, mm. 41, 40.

${ }^{88}$ Members of this group included Richard Walingford, Edmund Cook, William Gore, John Tyler, John Dene, John atte Grene, William Berewyk, Peter Webbe, John Wayte, John Garlek, Gilbert Beel, Thomas Payntour and Thomas Long. Walsingham, HA, vol. 1, 475 and Appendix B, 394; Réville, Soulèvement, 13, 17, 38, 152, 161; PROME, 'Parliament of 1381', item 63; KB 27/482, mm. 26, 26d, 28; KB 27/485, mm. 33, 33d; C 67/29, mm. 41-39. One interesting pardon that might be associated with the St Albans judicial hearings was granted to Thomas de Wycresley, 'for having cut the cords by which certain condemned men were being hung at St Albans', for which offence he had been detained in Newgate prison. CPR 1381-85, 43.

${ }^{89}$ Including John Yonge, Jordan de Bladyngton, Robert Draper, John Cheseman, John Clerk and Thomas Chaump. KB 27/482, m. 36; KB 27/483, m. 27d; KB 27/486, m. 11; Réville, Soulèvement, 183-4, 189, 205, 227; C 67/29, mm. 41-39.

${ }^{90}$ KB 27/482, m. 39. Other Londoners included Stephen Sunday, William Peche, John Huntingdon and Theobald Ellis, C 67/29, mm. 41-39.

${ }^{91}$ For further discussion of the list of those excluded, see below.

92 Eiden, 'Joint action', 9. Prescott notes that of all the pardons issued in connection with the revolt, only just over 40 were produced by defendants in court. He is surely right to suggest that many pardons would have been bought merely as a precaution (Prescott, 'Judicial records', 355).
} 
possibility is that these early pardons were linked with the king's itinerary in the days and weeks after the rebellion. It is interesting that they were largely granted to inhabitants of areas which hosted the royal entourage in June or July 1381. From the itinerary W. H. B. Bird pieced together, Richard left London for Havering and Chelmsford in Essex where he stayed for a week. After returning to London he went to Hertfordshire, spending a week in St Albans and another in Berkhamsted and King's Langley. The court then went to Reading Abbey, to Eltham and to Leeds in Kent before returning to London. ${ }^{93}$ This might account for the large group from south-west Hertfordshire; 44 of the 115 early pardons were granted to residents of Hertfordshire, almost all of whom lived within a 20 mile radius of St Albans. This also fits with the group from Kent, who came from the area surrounding the royal palace at Eltham. In contrast the numbers do not correlate with areas which had most recorded rebels - Norfolk and Essex were at the top of the list, while Hertfordshire had far fewer. ${ }^{94}$ If the numbers were simply dictated by proximity to the chancery at Westminster, it seems surprising that there are not more recipients from London itself.

The reasons for these pardons being given are not usually recorded. In two of the earliest pardons granted, there is explicit reference to the help of a patron interceding on the supplicant's behalf, so in the case of Paul Salesbury, the pardon was said to be given on the information of the king's chamberlain, Aubrey de Vere. For Richard Martyn of Cambridge, pardon came at the request of Anne of Bohemia, who was soon to be crowned queen. Anne was also named in the pardon drawn up by parliament; the king was said to have granted pardon at the special request of Anne, in order to encourage his subjects to keep the peace in the future. ${ }^{95}$ There are also three examples of letters ordering the restoration of confiscated lands, because 'men of the council learned in law' had concluded that the cause given by the escheator was not sufficient for forfeiture. ${ }^{96}$

It is also interesting that six of those who received early pardons were later named in parliament on the list of those excluded from royal grace. ${ }^{97}$ It might be that those who drew up the lists were simply unaware that these men had already been granted pardon. But it is also true to say that the pardons they had received did not excuse them if they were later implicated in the deaths of the senior government ministers, Sudbury, Hales and Cavendish, or the murder of the prior of Bury, or of the burning of the Savoy palace or Clerkenwell Priory. If this was the case there would be no contradiction in placing them on the list of those excluded. This can be proved true of one man, Stephen Sunday, who was granted pardon on 12 November, but was later accused of involvement in the murder of Robert Hales. ${ }^{98}$ A final point about these early

\footnotetext{
93 W.B. Bird, 'The peasant rising and the king's itinerary', English Historical Review, 31 (1916), 125.

${ }^{94}$ Eiden's figures: Norfolk (1,214), Essex (954), Kent (456), Suffolk (299), Cambridgeshire (242), Rest (389). Eiden, 'Joint action', 10, n.26.

95 See below.

96 Salesbury: C 66/311, m. 31, CPR 1381-85, 30-1; Peasants' Revolt, ed. Dobson, 228. Martyn: CPR 1381-85, 143, 203. Parliamentary pardon: PROME, 'Parliament of 1381', item 32. Letters to escheators: CCR 1381-85, 14, $169,175$.

${ }^{97}$ PROME, 'Parliament of 1381', item 63. John Yonge of Herefordshire (listed under London); Richard Scott, hosier, of London; Stephen Sunday, of Hackney; Thomas Bunny, sheather and grinder, of London; William de la Stable, alias William Gore of St Albans; John le Dene, pedlar, of Ashbocking in Suffolk.

${ }^{98}$ Another name on the list of exclusions was Thomas, servant of Paul Salesbury (see above, note 60). While Salesbury was the first to receive a pardon, his servant was not so lucky. Prescott notes that nearly 1 in 10 of those excluded were later found not guilty. He suggests that local commissioners adopted different criteria for deciding which names to put forward for exclusion. In London, it seems, Walworth's commission simply forwarded the names of those awaiting trial (Prescott, 'Judicial records', 358-61).
} 
pardons is that seven of the recipients went on to sue out another pardon in the spring of 1382 . Four of them came before King's Bench, and both pardons were noted in the record. Robert Brigham and John Refham of Cambridge were even able to produce two letters of pardon and letters of protection. ${ }^{99}$

Returning to the scholarly debate on the character of the government reaction, it has been argued that an initially harsh and vindictive campaign of repression gave way to a more moderate stance once the Commons were able to voice their concerns in parliament. ${ }^{100}$ However, this might be too neat a division to make. In fact, the issue of pardons before the opening of parliament suggests that they were a recognised part of the judicial process, and that they could, and would, be used as part of the government's response to the revolt. While they had not yet been sanctioned by parliament, this rubber-stamp was assumed to be only a matter of time in coming, and it was perfectly acceptable to issue pardons in the meantime. ${ }^{101}$ In the context of the chronicle narratives discussed above, these pardons are also consistent with the sense that royal mercy would be available to those judged worthy of receiving it, and that this form of grace could be dispensed by the young king without waiting for the sanction of parliament. Moreover, there is a suggestion from certain of the chroniclers that concerns were being expressed among sections of the local gentry communities about the activities of the royal commissioners sent from Westminster. According to Walsingham, prominent members of the gentry in Kent and Hertfordshire had offered to stand surety for the commons, rather than see a royal visitation of their counties. ${ }^{102}$ Nigel Saul suggests that this was prompted by a growing belief that the campaign of repression had been pushed too far. ${ }^{103}$ It might also be the case that local gentry wanted power to deal with local rebels themselves, rather than cede authority to the judicial commissions sent from Westminster. A petition of the abbot and convent of Peterborough, for example, requested authority over correction of their own tenants. They also asked for charters of pardon to be withheld until the individuals concerned had made satisfaction for their rebellion. ${ }^{104}$ This is particularly interesting in light of the debate surrounding the social exclusivity of the law. The supposed corruption of local gentry justices was apparently a central concern of the lower social orders, and one which was articulated by the chroniclers. In this instance, however, it was the gentry suspicion of the officers of central government which Walsingham chose to articulate.

By 30 August the Crown had halted all arrests and executions and adjourned outstanding hearings into King's Bench. ${ }^{105}$ Writs for attendance at parliament had already been sent out,

\footnotetext{
99 John Refham, Robert Brigham (note 73 above), Gamelin Impey, William Phippe, Thomas Longe (KB 27/485, m. 33), Peter Webbe and Jordan de Bladyngton (note 79 above). C 67/29, m. 28, 26, 25.

100 Tuck, 'Nobles, commons'; Ormrod, 'Government'.

101 Parliament was originally called (by writs of 16 July) for 16 September, but was postponed until the beginning of November. It was then adjourned on 13 December to meet again between 27 January and 25 February 1382 (Peasants' Revolt, ed. Dobson, 325). For further discussion see below.

${ }^{102}$ HA, vol. 2, 14, 22-6.

${ }^{103}$ Saul, Richard II, 78-9.

104 SC 8/94/4698. The tenants had been indicted before Lord de la Zouche's commission.

${ }^{105}$ CCR $1381-85,7-8$.
} 
so it is possible that these measures were designed to appeal to the representatives in parliament. ${ }^{106}$ It is also possible that the council themselves favoured a general pardon. A meeting of the council was held on 7 October in Berkhamsted. The main focus of attention at this meeting were plans for the king to lead a campaign to France and capitalise on the political weakness created by the death of Charles V. ${ }^{107}$ If such a campaign were to go ahead, the nobles would be needed to lead the army, rather than to head up judicial commissions at home. It is possible that the council also considered the financial benefits of granting a pardon. The Anonimalle author made the point explicitly when he commented that 'everyone was to have his charter of pardon and pay the king as fee for his seal twenty shillings, to make him rich'. ${ }^{108}$ What is clear is that the idea of pardoning the insurgents was not new to the parliament which met in November. It is also evident that in issuing these early pardons the young king was assuming, or at least being given a central role in affairs, a role consistent with the narratives of the chroniclers.

\section{III}

The discussion of pardon in the parliament convened on 3 November 1381 has received some scholarly attention. The debate has centred on the conflicting aims of the Lords and Commons; did the peers favour a swift and harsh brand of justice which would allow them to resume the war with France, and did the Commons exert pressure to enforce a more moderate stance $?^{109}$ While these questions are pertinent, it is also important to retain the sense of these parliament rolls as texts, and to view them in a broader context, alongside the chronicle accounts and the legal records. Much of the language of the Common petitions and the terms used in the royal grant of pardon, for example, drew on a discourse of pardon familiar from earlier grants of general pardon, and in this sense the Crown self-consciously sought to ground its action in the precedent set by past acts of grace.

While it might be true to say that certain of the magnates were focused on a foreign campaign, it does not necessarily follow that the grant of pardon was forced on them against their will. It is dangerous to assume that pardon was solely a policy of the Commons, designed to promote reconciliation, as a precursor to pushing forward their agenda of thoroughgoing reform. Indeed, it was the Crown's representative, the treasurer, Sir Hugh Segrave, who first

\footnotetext{
106 The place-dates on the letters patent recorded on the pardon roll indicate that Richard had reached Westminster by 20 October (C 67/29, mm. 41, 40, 39). This would suggest that warrants for all the 'early' pardons were issued from the time Richard arrived in Westminster until shortly before the schedule of pardon was submitted in parliament. The only exceptions were the pardons to Salesbury and possibly that to Wycresley - Salesbury's was dated 22 July, and issued from Berkhamsted (CPR 1381-85, 30), Wycresley's on 10 October from Berkhamsted (CPR 1381-85, 43). It is unlikely that the warrants were given before this time as it was customary for letters patent to bear the date of the original royal warrant: H.C. Maxwell-Lyte, Historical notes on the use of the Great Seal in England (London, 1926), $247-8$. A.L. Brown, 'The authorisation of letters under the Great Seal', Bulletin of the Institute of Historical Research, 37 (1964), 125-55, notes that the warrant per ipsum regem on letters of general pardon was a fiction, indicating not that a warrant had been issued for every individual, but referring instead to the original grant. See also B. Wilkinson, 'The authorisation of Chancery writs under Edward III', Bulletin of the John Rylands Library, 8 (1924), $107-39$.

107 A. Goodman, John of Gaunt. The exercise of princely power in fourteenth century Europe (London, 1992), 89, n.9, citing writs of summons E 403/485/14. Tuck, 'Nobles, commons', 209.

108 Peasants' Revolt, ed. Dobson, 305-6. Income from the third poll tax had been $20 \%$ lower than predicted, and, as Saul comments, a main object of summoning parliament was to address the state of royal finances. Saul, Richard II, 79, 104. See also Tuck, 'Nobles, commons', 203-4.

109 Tuck, 'Nobles, commons', 207-9; Ormrod, 'Government', 22; Ormrod, 'Joan of Kent', 287-91.
} 
mentioned the idea of pardon in the opening speech. He outlined the king's desire to make an ordinance which would bestow 'peace and tranquillity' upon the realm, and his willingness to grant a general pardon if parliament authorised him to do so. ${ }^{110}$ But to say that the government was ready to countenance the idea of pardon is not to say that they were earnestly looking to implement the fundamental reforms put forward by the Commons. ${ }^{111}$ In contrast, Sir Richard Waldegrave's speech as speaker of the Commons expressed a different attitude to the pardon. He suggested that the issue of a pardon was a chance to reawaken the sense of obligation among the king's subjects, and to encourage officials to perform their duties conscientiously. The rebels, he said, had been forced to take action by burdensome taxation and mistreatment at the hands of royal officers, and the government's response should comprise reform and reconciliation. ${ }^{112}$ These twin aims were articulated in his proposal for ministers to be appointed to implement reforms and for grace to be granted to all the king's subjects. This endorsement of the complaints of the insurgents, despite the danger of exacerbating unrest and disorder in the realm, perhaps speaks of shared political frustrations. ${ }^{113}$

Ultimately, the Crown would grant a pardon on its own terms. On 13 December, the king gave his assent to the ordinance of pardon in the form the Commons had devised. However, when the Commons refused to countenance an extension of the wool subsidy, the Crown used the pardon as a bargaining chip.

... it was replied on the king's behalf that it had not been customary in parliaments in the past, for a general pardon and such grace to be had from the king, when the commons wished to grant the king nothing ... To which the commons again replied that they would further discuss and consult on their grant to be made of the subsidy on wool, and it was then said on the king's behalf that the king would consider his said grace until the commons had done for their part that which pertained to them. ${ }^{114}$

The Crown's stance had the desired result: the Commons consented to the subsidies on wool. In 1377, when the Crown had granted a general pardon to mark the occasion of Edward III's fiftieth year on the throne, the link between agreement to a subsidy and the grant of a general pardon had been implicit. ${ }^{115}$ In 1381 the conditional nature of the grant was explicitly emphasised. By 1398 the Crown was prepared to spell out the conditional nature of the grant: 'And the king our sovereign lord, upon the grant of his grace and pardon ... made an open declaration by his own mouth. So that if the lords and commons of the realm do put or make any let or disturbance contrary to the grant of the said subsidy of wools so granted to him for term of his life, that then the said grace and pardon shall be void and clearly annulled'. ${ }^{116}$ Clearly, the government felt itself to be in control of the situation. It authorised the charters of pardon and every subsequent amendment. But it was prepared to use the grant as a bargaining tool when taxation was at stake. The issue of a pardon also contained the implicit assumption that the rebels

\footnotetext{
$\overline{110}$ PROME, 'Parliament of 1381', item 8.

111 The government's failure to institute administrative reform is demonstrated in Ormrod, 'Government', 25-30.

112 PROME, 'Parliament of 1381', items 17-27: The Commons suggested thoroughgoing reforms to the royal household, administration and judiciary.

113 PROME, 'Parliament of 1381', item 28; Watts, 'Pressure of the public', 177.

${ }^{114}$ PROME, 'Parliament of 1381', item 39. For the use of this 'supply and redress' formula elsewhere, see: W.M. Ormrod, 'Agenda for legislation, 1322-c.1340', English Historical Review, 105 (1990), 1-33; The English parliament in the middle ages, ed. R.G. Davies and J.H. Denton (Manchester, 1981), 34-87.

115 PROME, 'Parliament of 1377', items 7, 19, 24-6.

${ }^{116} S R$, vol. 2, 106-7. The general pardon of December 1414 was also conceded in return for a tax subsidy.
} 
wanted to be reconciled with the Crown, and that the Crown, while it could take further repressive measures if it chose, was generously exercising its prerogative of mercy. In the case of the pardon at least, the Crown could maintain that it was not pushed into a corner by a hostile parliamentary Commons. Nor was it forced to implement a desperate measure of last resort in the face of an unprecedented rebellion.

The way in which the pardons were formulated in parliament is interesting. The schedule presented by the Commons contained three kinds of grace and pardon, only one of which concerned the rebels. ${ }^{117}$ The first granted an amnesty to all lords who had acted 'without the due process of law' in quelling the rebellion; the second allowed for accused rebels to sue out a pardon, although there were certain named exceptions; and the final clause allowed for anyone not involved in rebellion to purchase general pardons as a reward for their loyalty. ${ }^{118}$ This third type of pardon was by far the most popular, and was purchased by many people who lived in areas unaffected by revolt. ${ }^{119}$ The distinction between these three types of pardon was also maintained on the pardon roll. ${ }^{120}$ The roll has three distinct sections, the first of which records the 'early' pardons granted before the opening of parliament. But at the end of this first list, the diplomatic alters considerably, indicating the change in procedure to accompany the parliamentary issue. There is a new letter patent copied into the roll at this point, which is phrased in the same way as the form of grace drawn up in parliament and issued specifically to the rebels. ${ }^{121}$ This pardons the individual all felonies and treasons committed during the insurrection, defined as lasting from 1 May until 1 November. The letters also repeat the terms recorded on the parliament roll in specifically excluding those who killed Simon Sudbury, Robert Hales and John Cavendish. There is also a change in the way the names are recorded; they are now divided into counties, with inhabitants of the same town grouped together. It seems that either the chancery clerks were keeping a memorandum of the pardons grouped under geographical location, and then writing them up in fair copy, or that the names were already recorded in lists drawn up at the county level. ${ }^{122}$ There are 547 names in this first section associated with 25 different regions, mostly in areas associated with the revolt. After this, there seems to be a third, distinct section, headed by a different letter patent. ${ }^{123}$ The letter makes no mention of the murderers of Sudbury, Hales or Cavendish. Instead it echoes the general terms of the third grace on the

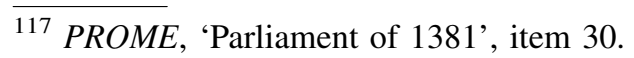

118 PROME, 'Parliament of 1381', items 30-4; Peasants' Revolt, ed. Dobson, 331-3.

119 See Fig. 1.

${ }^{120}$ PROME, 'Parliament of 1381', items 31-4; Peasants' Revolt, ed. Dobson, 331-3. Andrew Prescott argues that it is impossible to distinguish which of the pardons listed in this roll were given to rebels, and that it does not help to identify participants in the rising (Prescott, 'Judicial records', 354). However, there do seem to be three distinct sections to the roll, separating 'rebel' pardons from 'general' pardons. It is true, of course, that those buying a 'rebel' pardon were not necessarily insurgents.

${ }^{121}$ The 'early pardons' are listed on the first three membranes - mm. 41-39. At the head of membrane 38, a new letter patent denotes the new section. This letter is repeated on $\mathrm{mm} .29$ and 26 . This section appears to end on $\mathrm{m}$. 25. On $\mathrm{m}$. 24 is a new letter patent denoting the third section.

${ }^{122}$ If the latter suggestion were accurate, then the sheriff or parliamentary representative would be the most likely figure to pass on this information.

${ }^{123}$ This begins on $\mathrm{m}$. 24. The distinction is also observed in the letters recorded on the main patent roll. C.M. Barron notes a similar distinction on the 1398 rolls, between pardons given to those who had supported Gloucester and Arundel in 1386-7 and general pardons. C. M. Barron, 'The tyranny of Richard II', Bulletin of the Institute of Historical Research, 41 (1968), 7-9; A. Goodman, The loyal conspiracy. The lords appellant under Richard II (London, 1971), $36-41$.
} 


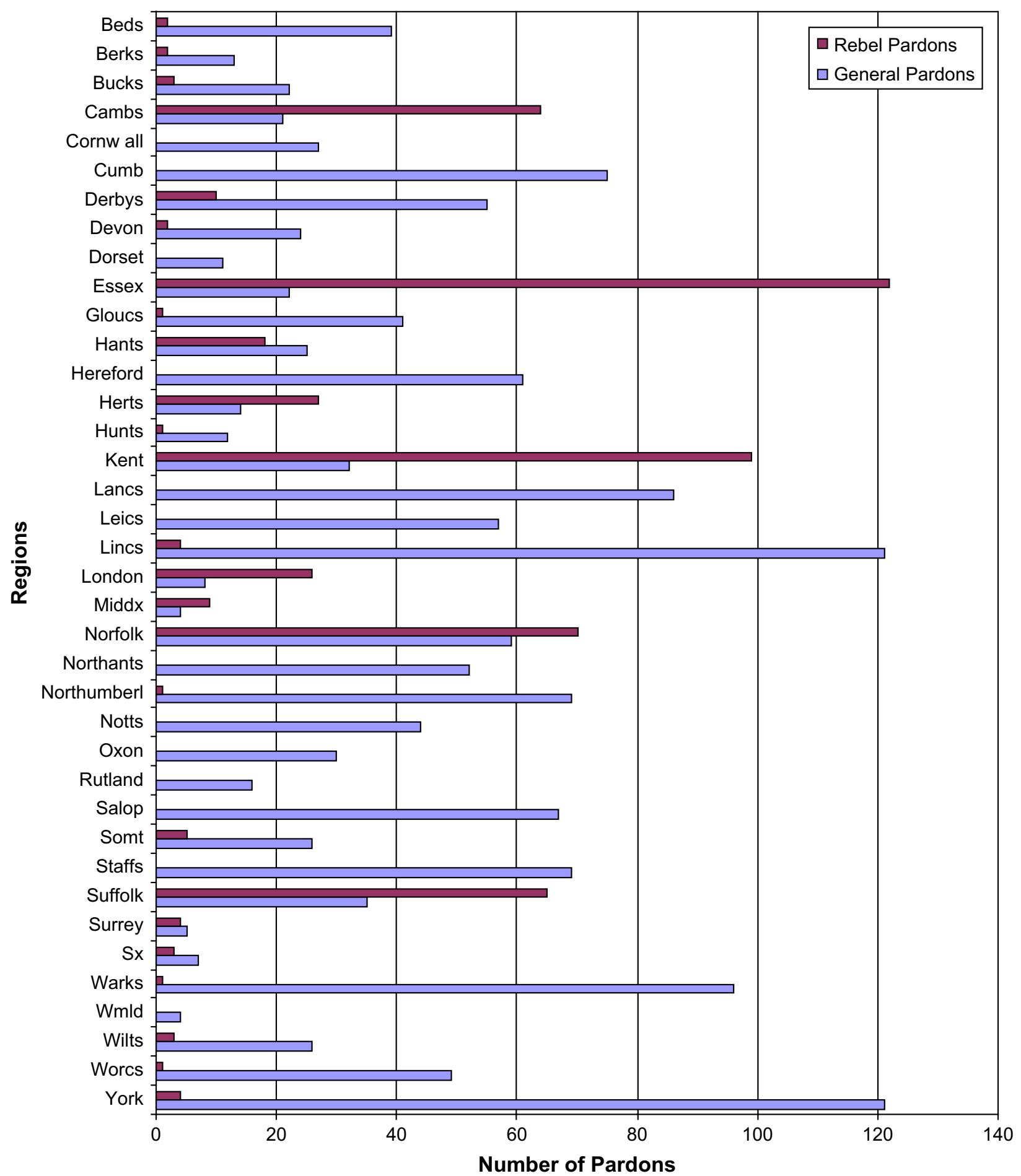

Fig. 1. Graph showing the regional distribution of pardons.

parliament roll. The recipient is pardoned all manner of felonies committed before 14 December. ${ }^{124}$ The impression that this is a new section is reinforced by the run of dates, which breaks off at this point at May 1382 and begins again at December 1381. In contrast to the

$\overline{{ }^{124} \text { C 67/29 }}$, m. 24; PROME, 'Parliament of 1381', item 106, gives the recommended text of the pardon, amended at the request of the Commons to include those detained in prison for felony on 13 December. This form was adopted largely unaltered. 
previous section, this group contains close to 2500 names from 39 different regions, including areas little affected by the revolt. ${ }^{125}$ It, therefore seems probable that this second section contains the names of those suing out pardons under the terms of the third grant to the 'good and loyal' commons. The numbers involved are comparable to the general pardons of 1377 and 1398. The former was again given to almost 2500 people, while in 1398 the figure went up to over $4000 .^{126}$

The reason it was deemed necessary to issue this last, comprehensive pardon, and to reissue it (although this time only for trespass) in October 1382, seems to be tied to the government's desire to ground their action in precedent. ${ }^{127}$ In adopting the machinery and language of the general pardon, the government could look back to established procedures for the solution rather than forward to fundamental administrative reform. By setting the pardons for the rebels within the context of the general pardon, the Crown and the county representatives could also adopt defined roles, one as the source of royal grace and mercy, the other as the supplicant for it. It was a discourse that had been rehearsed most recently in the general pardon of 1377, issued soon after the turmoil of the Good Parliament. A comparison of the language used in the parliament rolls of 1377 and of 1381 reveals the extent of the similarity. Edward III, it was reported to parliament, had the utmost compassion for the 'very great charges and losses' which his people had borne, and was therefore willing to make 'greater grace than he ever made before', so that his commons could be 'the better comforted and take heart to do better in times to come. ${ }^{, 128}$ The pardon was to represent the mutual obligation between the king and his subjects. Richard's pardon echoed such sentiments:

our lord the king considering that the lieges and subjects of his said realm, from the time of his coronation until the said insurrections and uprisings, had conducted themselves well, governed themselves peaceably, and shown him favour and good will in all his needs and affairs ... out of reverence for God and His sweet mother St Mary, and at the special request of the noble lady, the Lady Anne, daughter of the noble prince Charles, late emperor of Rome, soon, if it please God, to be queen of England; and also to the end that the same subjects should be the more strongly inclined to remain faithful and loyal in future, as they were before the said uprising; of his special grace he has pardoned the said commons. ${ }^{129}$

Richard recognised the enduring loyalty of his subjects, and issued the pardon to reaffirm his commitment to the reciprocal relationship between the Crown and the commons. The text of the pardon helped to give it a recognisable context, and to suggest that it was within the competence of the minority government to deal with the threat posed by the revolt. It is also worth noting that in framing the pardon in terms of loyalty and forgiveness, the Crown was drawing on a religious discourse that the rebels themselves had tried to appropriate. As Margaret Aston demonstrated, the insurgents had used the feast of Corpus Christi on 13 June to

\footnotetext{
125 The last six membranes of this section date from May 1383-January 1398 and list 588 names. The ordinance, however, stipulated that all pardons should be obtained before 2 June 1382. Despite this, these pardons are also headed by letters patent in the form which the ordinance prescribes. There are also 13 general pardons recorded on the main patent roll which were issued after 2 June 1382: CPR 1381-85, 179, 182, 206, 211, 212, 213, 236, 242, 272.

${ }^{126} 1377$ - C 67/28B (2,439 names); 1398 - C 67/30 (3,511 names) and C 67/31 (680 names).

127 PROME, 'Parliament of 1382', item 43.

${ }^{128}$ PROME, 'Parliament of 1377', item 24 (answer).

${ }^{129}$ PROME, 'Parliament of 1381', item 32.
} 
mobilise supporters and to coordinate their move on London. ${ }^{130}$ But this was a festival dedicated to unity and to reciprocal obligation through the New Covenant of Christ, and the Crown now demonstrated itself to be the guardian of these values. The royal pardon reunited the king with his subjects, in return for the promise of future loyalty. ${ }^{131} \mathrm{In}$ issuing a pardon at this time, the government also echoed the common practice of granting indulgences to those attending church on Corpus Christi Day. ${ }^{132}$ The theme of pardon on this day was reinforced in the pageant cycles - the Towneley Corpus Christi play The killing of Abel, for example, contained a scene in which Cain proclaimed a royal pardon for his servant. ${ }^{133}$ This was not the first time a royal pardon had drawn on the example of ecclesiastical practice - in 1377 the general pardon alluded to Judeo-Christian notions of jubilee (the completion of Edward III's fiftieth year on the throne) as a time of remission of punishment for sins and restitution of property. 134

It is true to say, however, that in 1381 the Crown was using the procedures of the general pardon for a new purpose, and in so doing amended some of the familiar terms. The 1381 general pardon, for example, did not contain the detailed clauses concerning land ownership and property rights of the 1377 grant. Similarly, the 1382 statute contained a general pardon for all trespasses, but not for the treasons and felonies that the 1381 pardon had addressed. ${ }^{135} \mathrm{~A}$ more prominent departure from precedent was the reference to Queen Anne's intercession in the text of the pardon itself. The intercessory role of medieval queens is, of course, well-attested. ${ }^{136}$ But previous grants of general pardon had not made such a reference, perhaps because this form of pardon was represented as a munificent bestowal of royal grace, a gift of grace from the monarch to reward the loyalty of his subjects. It was not intended to be seen as royal forgiveness for a particular act of defiance or disobedience, and therefore it did not require the legitimising use of the feminine intercessor to justify the setting aside of masculine ideas of vengeance. The 1381 pardon similarly evokes this idea of mutual obligation, and the loyalty of the king's subjects. In this instance, however, it seems that further justification is needed - the pardon is granted out of 'reverence for God and His sweet mother St Mary' and 'at the special request of the

\footnotetext{
${ }^{130}$ M. Aston, 'Corpus Christi and corpus regni: heresy and the Peasants' Revolt', Past \& Present, 143 (1994), 3-47; M. Rubin, Corpus Christi. The Eucharist in late medieval culture (Cambridge, 1991).

131 J. A. Keen, The charters of Christ and Piers Plowman: documenting salvation (Oxford, 2002).

${ }^{132}$ Urban IV instituted indulgences for all who attended church for matins and evensong on Corpus Christi Day and during its octave, see: Calendar of entries in the papal registers relating to Great Britain and Ireland: Papal Letters, vol. 4 1362-1404, ed. W.H. Bliss, and J.A. Twemlow (1902), 165; Aston, 'Corpus Christi', 19; Rubin, Corpus Christi, 213, n.4.

${ }^{133}$ Wakefield pageants, ed. Cawley, xiv-xvii. Cawley suggests that performance of the pageants predated the text. See also B.A. Brockman, 'The law of man and the Peace of God: judicial process as satiric theme in the Wakefield Mactacio Abel', Speculum, 49 (1974), 699-707.

134 Ormrod, "Fifty glorious years", 13-20.

135 The 1382 statute seems to have addressed specifically the issues raised by the Commons concerning the fear of false indictment.

136 J.C. Parsons, 'The queen's intercession in thirteenth-century England', in: Power of the weak: studies on medieval women, ed. J. Carpenter and S.-B. MacLean (Urbana, 1995), 147-77; J.C. Parsons, 'The intercessory patronage of Queen Margaret and Isabella of France', in: Thirteenth-Century England VI, ed. M. Prestwich, R. Britnell and R. Frame (Woodbridge, 1997), 144-56; P. Strohm, Hochon's arrow (Princeton, 1992), 95-119.
} 
noble lady, the Lady Anne'. The novelty of the situation and the insecurity of the minority regime were, perhaps, coming to the surface. ${ }^{137}$

At the same time that the pardon was drawn up, a list of those to be excluded was also compiled. It contained the names of 287 people said to be principal instigators of revolt. ${ }^{138}$ Also excluded were all inhabitants of Canterbury, Bury St Edmunds, Beverley, Scarborough, Bridgwater and Cambridge, all approvers and those appealed, those who killed Simon Sudbury, Robert Hales and John Cavendish, and those who had escaped from prison. ${ }^{139}$ These terms were soon to be moderated. All the exempted towns were pardoned, apart from Bury St Edmunds. As far as Bury was concerned, the prior and convent of the town had themselves petitioned the king to ask that the townsfolk be denied a pardon until they had given sufficient security for keeping the peace in the future. ${ }^{140}$ Further amendments saw the inclusion of those who were detained in prison for felony on 13 December and those whose approver was not still alive. It was also stipulated that charters already sealed were to be amended free of charge. ${ }^{141}$

One further, important amendment was made in the parliament of October 1382. At this meeting, the Commons raised concerns about the availability of the pardon. ${ }^{142}$ In an echo of the rebels' earlier complaints of malicious indictment, the Commons now asserted that many of the people indicted for treasonous action during the uprising were innocent, but too poor to purchase charters of pardon and were therefore placed outside the protection of the king's peace. They suggested that the solution was to issue a general pardon for treason free of charge, without the need to sue out a personal copy:

a large number of the people who were indicted for treason because of the said uprising are labourers and the like who have nothing, and are not in a position to purchase their charters, so that they remain without the same pardon: and because they fear that they will be placed in exigent or outlawry, or seized and put to death, they flee into woods and other places, and what is more, a large number of others who have not been indicted fear the same plight, from which great trouble may ensue. On account of which may it please you to grant a general pardon of treason in the aforesaid uprising, excepting those who were excluded, without a charter being necessary... ${ }^{143}$

The king's favourable reply represented an unprecedented grant of royal mercy. All the subjects of his realm were to be pardoned any treasons and felonies committed in the uprising (between 1 May and 24 June 1381). The only people excepted were those 287 on the list of

\footnotetext{
137 Mark Ormrod has suggested that this reference to Queen Anne allowed the government to legitimise its volte-face from a policy of repression to reconciliation in the November parliament. I have portrayed the idea of pardon as less innovative, and less directly related to the influence of the parliamentary Commons, than has previously been supposed. But when it came to drafting the terms of the general pardon in parliament, the novelty of the situation showed through in the elaborate justification, despite the government's attempts to ground their actions in precedent and downplay the scale of the threat. Ormrod, 'Joan of Kent', 288.

138 The names were submitted to parliament: PROME, 'Parliament of 1381', item 63.

139 PROME, 'Parliament of 1381', item 32.

${ }^{140}$ SC 8/95/4703.

${ }^{141}$ PROME, 'Parliament of 1381', item 106.

142 This had been preceded by the issuing of charters of pardon to York, Scarborough, and Beverley: PROME, 'Parliament of 1382', item 18-21. The copy for York was kept in the city archive, dated 18 October 1382. No further 'rebel' pardons are recorded on the supplementary roll after the 2 June deadline, but there are several on the main patent rolls: CPR 1381-85, 158, 159, 173. Thomas Bordefeld (13 July 1382); John Mylot (16 July 1382); Thomas de Middelton (20 October 1382).

${ }^{143}$ PROME, 'Parliament of 1382', item 43. See also a petition for the 1381 pardon to be extended - SC 8/174/8684.
} 
principal insurgents, three additional named citizens of London, and the inhabitants of Bury St Edmunds. ${ }^{144}$ For the first time ever, a comprehensive general pardon had been granted free of any requirement to purchase letters patent and thus automatically extending the king's mercy to all his subjects. ${ }^{145}$ Such a concession was remarkable since, apart from its novel nature, it meant the king conceded his rights to a potentially lucrative source of revenue in the fees charged for copies of letters patent. For the pardons already issued, the amount received must have been over $£ 2000 .{ }^{146}$ In line with this blanket amnesty, there are several examples recorded on the close rolls of orders to the justices of the peace in a particular county 'not to trouble' named inhabitants because of the agreement the king had made to pardon all his subjects, 'of whatever estate or condition. ${ }^{147}$ This amnesty reflected the fears of the wider community concerning the threat of false indictment without the protection of a letter of pardon. In a few cases the terms of the pardon explicitly stated that the recipient had been falsely accused. In 1383, for example, two men received pardons after it was decided at King's Bench that they had been indicted by their enemies. ${ }^{148}$ The pardon also ensured that the full resources of the judicial system could be focused on prosecuting those individuals who had been exempted from the amnesty.

The end of the amendment and reissue of the pardon seems to have been signalled in the 1383 parliament. The Commons now requested that no one should be excluded from the amnesty except the 287 named individuals, and asked that anyone indicted because of the insurrection would be released by this pardon. They also wished to set a terminal date of 7 July 1383 for anyone to bring a suit connected with the insurrection and to allow for the acquittal of anyone who could present the testimony of three or four worthy men. The king granted these requests in a final statute promulgated on 18 May $1383 .{ }^{149}$ New judicial proceedings were initiated against those 287 individuals who had been excluded from the pardon. The

\footnotetext{
${ }^{144}$ Except trespass touching lands and tenements, trespasses made by the officers of the king and of great lords, and jurors and maintainers of quarrels.

${ }^{145}$ PROME, 'Parliament of 1382', item 49; SR, vol. 2, 29-30. They adopted the standard procedure of excepting treason, murder, robbery, and the rape of women and asked that no justice of eyre nor trailbaston be sent for offences committed before this time. Prescott notes that it was no longer necessary to purchase letters of pardon to benefit from the amnesty, but letters close could be obtained if necessary for court proceedings, and were free of charge (Prescott, 'Judicial records', 356, n.61).

146 A.L. Brown suggests that in 1433 chancery would have been expected to produce total profits of, at most, £2000. A. L Brown, The governance of late medieval England, 1272-1461 (London, 1989), 65. Instead of the charters of pardon, letters close were apparently made available after the concession of 1382 , but were not recorded on the supplementary roll. These, it seems, could be obtained without payment and had the same effect as earlier charters of pardon. KB 27/487, m. 19d; KB 27/488, mm. 8, 19; KB 27/489, mm. 18, 21, 24d; KB 27/490, mm. 21, 21d; KB 27/493, m. 4; KB 27/494, m. 14.

${ }^{147}$ CCR 1381-85, 165, 185-6, 258, 259, 267, 277, 372. Those who had been exempted from the amnesty, but were subsequently pardoned, were still issued individual letters patent. However, nine letters patent on the main roll were issued after the 24 October amnesty, to rebels who had not actually been exempted. It is not certain why these pardons were issued, as the amnesty of 24 October removed the obligation to sue for individual letters. Three seem to have been renewals of pardons sealed at another time: $C P R$ 1381-85, 203, 215, 399. Two state that they are exemplifications of the 24 October amnesty, suggesting that court proceedings had been initiated against them before this date: $C P R$ $1381-85,224$.

${ }^{148}$ KB 27/501, m. 1d; CPR 1381-85, 272; SC 8/262/13099; KB 27/488, m. 25. Prescott notes that the list of those excluded from the pardon in 1381 had been badly affected by false accusation (Prescott, 'Judicial records', 358-9). Reform of the judicial system had long been on the political agenda of the Commons, echoing the contemporary perception that the quality of the legal system was degenerating. Musson and Ormrod, Evolution, 161-93; E. Powell, 'The administration of criminal justice in late-medieval England: peace sessions and assizes', in: The political context of law: proceedings of the seventh British history conference, ed. R. Eales and D. Sullivan (London, 1987), 49-59.

${ }^{149}$ PROME, 'Parliament of February 1383', item 17; SR, vol. 2, 30-1.
} 
government sent these names to the King's Bench and the justices accordingly issued new orders for the arrest of the indicted. ${ }^{150}$ However, this action merely repeated proceedings taken by local commissions and as a result there seem to have been no additional convictions. Several of those named on the list were victims of false accusation. The names were supplied by local commissions and it seems likely that in London at least the commission simply forwarded to chancery the names of those against whom prosecutions were outstanding. About 50 of those excluded from the general pardon appeared in King's Bench between 1383 and 1398, but almost all were acquitted or produced special letters of pardon granted at the request of an influential intermediary such as the queen or the mayor of London. ${ }^{151}$

\section{IV}

This examination of the role of pardon and mercy in the events of 1381 has suggested that a picture of government-led repression, halted only by the moderating voice of the parliamentary Commons, is perhaps too clear cut. Similarly, the idea that pardon was commonly associated with more concrete governmental and bureaucratic reform needs to be questioned. Looking first at the chronicle accounts of events, it is true, as Pearsall says, that the dominant models or images through which the writers sought to understand the revolt were of human wickedness, and violation of a divinely ordained hierarchy, of reason and nature being overturned. ${ }^{152}$ But another model that can be identified is that of the quality of royal mercy, the sense that petitioning the monarch in the case of false accusation or mistreatment at the hands of officials was the legitimate avenue of complaint, and would be met with a judgement from the king based on principles of equity and mercy. This was a model which appeared not only in the court literature of advice, but also in poems like the Outlaw's song of Trailbaston in the complaint tradition and in Corpus Christi plays like the Killing of Abel. ${ }^{153}$ It was a model, too, which was reflected in the actions of the rebels, in their evocation of an idealised judicial relationship between the king and his subjects, and in their construction of themselves as spokesmen for the commons, with implicit political rights.

The judicial and administrative records produced in the immediate aftermath of the revolt again demonstrate that ingrained notions of pardon could sit alongside repressive measures. Whether or not large numbers of rebels were executed, the idea of pardon had been in circulation since the rebels had first gathered on Blackheath, and it was assumed to be one option available to the justices who headed the first judicial commissions. The issuing of pardons to

\footnotetext{
$\overline{150 \text { PROME }}$, 'Parliament of 1381', item 63; KB 27/487, mm. 5, 6, 11, 11d; KB 27/488, m. 4.

${ }^{151}$ Prescott, 'Judicial records', 356-7. Prescott found 29 such pardons in the King's Bench rolls — Prescott, 'Judicial records', 357, n.68. It appears that 14 were recorded on the main patent roll, of which 11 were subsequently presented in King's Bench: Thomas Sampson, CPR 1381-85, 226; John Awedyn, CPR 1381-85, 238 (KB 27/488, m. 23); Thomas Engilby, CPR 1381-85, 270 (KB 27/503, m. 12); John de Spayne, CPR 1381-85, 272 (KB 27/501, m. 1d); William de Benyngton, $C P R$ 1381-85, 297; John Ellesworth, CPR 1381-85, 377 (KB 27/501, m. 15d); Thomas atte Raven, $C P R$ 1381-85, 409 (KB 27/490, m. 20); Richard Redyng, CPR 1385-89, 25 (KB 27/512, m. 22d); Henry Nasse, CPR 1385-89, 75 (KB 27/513, m. 7); Robert Wesebrom, CPR 1388-92, 186 (KB 27/523, m. 19d); William Pypere, CPR 1388-92, 290 (KB 27/535, m. 10d); Thomas Wyllot, CPR 1388-92, 457 (KB 27/522, m. 13); William Pykas, CPR 1392-96, 362 (KB 27/531, m. 14d); Robert Priour, CPR 1396-99, 109 (despite the claim in his letter patent, he does not seem to have been on the list of the excluded).

152 Pearsall, 'Interpretative models', 64-5; Peasants' Revolt, ed. Dobson, 367-72.

153 Gower, Confessio amantis, ed. Peck, book 7, 11. 3103-17; Rymes of Robin Hood, ed. Dobson and Taylor, 253; Wakefield pageants, ed. Cawley; Watts, 'Pressure of the public', 168-9.
} 
certain of the rebels at an early stage was not seen as irreconcilable with the idea of strict, even harsh justice. Recourse to pardoning was assumed to be intrinsic to the operation of the judicial system, rather than necessarily the herald of a distinct 'policy' of reconciliation. The issuing of pardons in the immediate aftermath of the revolt also gave a central role to the young king, who did not need to wait for parliament to ratify grants of royal grace.

Finally, it is useful to view the 1381 pardon in the light of past grants of royal mercy. In 1377, following the political turmoil of the Good Parliament, Edward III issued a pardon to symbolise reconciliation between the Crown and the political elite. In 1381, it was evident that the pardon was a gesture that harked back to past grants of royal grace for the solution rather than forward to fundamental administrative reform. ${ }^{154}$ Suggested changes to the procedures of chancery and exchequer were never taken up, and certain of the king's favourites continued to exercise an overbearing political influence. In the light of the precedent set by earlier general pardons, it seems that the minority administration was attempting to draw on established notions of political reconciliation and routinise the issue of pardons in order to pull themselves back from the brink of crisis. The general pardon perhaps even raised public expectations for reform that the Crown had no intention of implementing.

Helen Lacey took her Ph.D. at the University of York in 2005 and then held a temporary lectureship in medieval history at Durham University. She currently holds a stipendiary lectureship in late medieval history at Mansfield College, Oxford. Her research focuses on later medieval political culture and the social context of the law. She is especially interested in the influence of concepts of mercy in political culture, legal theory, and in the lives of those subjects who had reason to deal with the law courts. Her doctoral work, based on an interdisciplinary approach which brought together a range of governmental, judicial and literary texts, examined the use of the royal pardon in fourteenth-century England.

\footnotetext{
154 A. Gransden refers to the disillusionment expressed by chroniclers in the 1390s who had, only a decade before, glorified Richard's stance against the insurgents. A. Gransden, Historical writing in England 2: c.1307 to the early sixteenth century (London, 1982), 157-93.
} 